MARCO ALONSO ENCISO HOYOS

Caracterização da atividade ovariana no Urso-deóculos (Tremarctos ornatus Cuvier, 1825) mediante análise de metabólitos fecais de esteróides sexuais

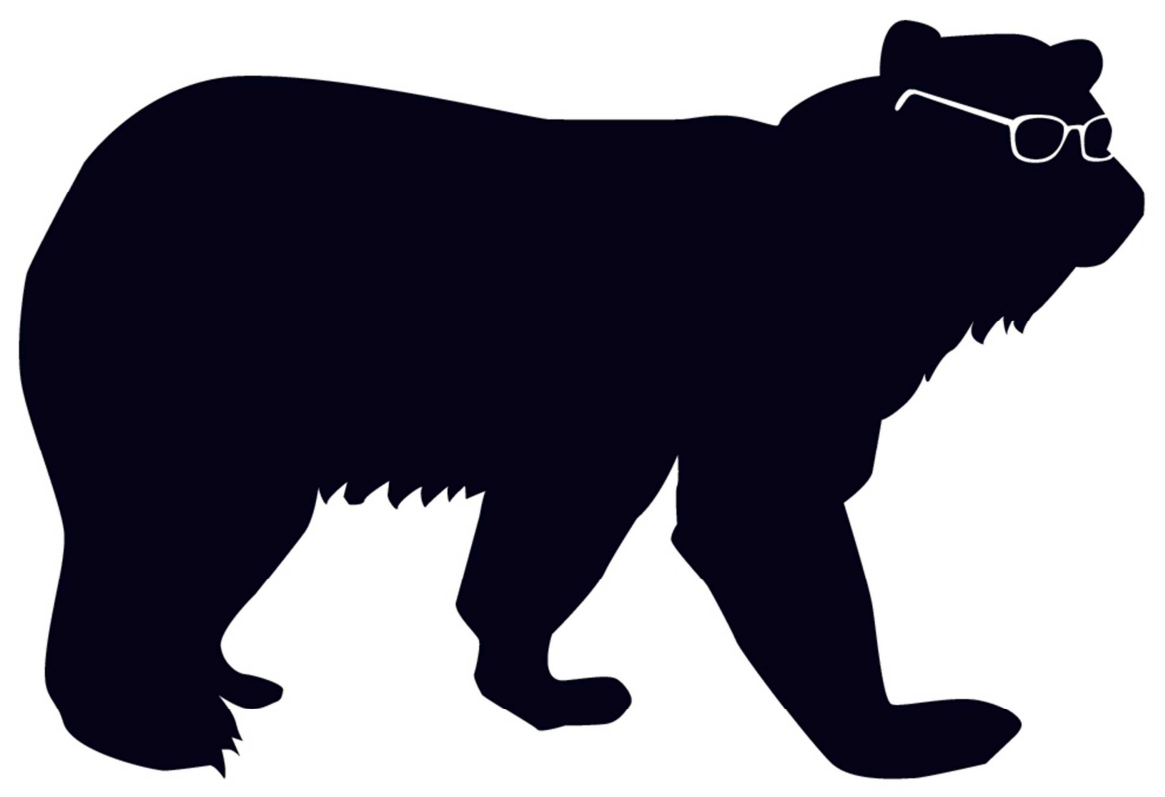

São Paulo

2013 
MARCO ALONSO ENCISO HOYOS

\section{Caracterização da atividade ovariana no Urso-de- óculos (Tremarctos ornatus Cuvier, 1825) mediante análise de metabólitos fecais de esteróides sexuais}

Tese apresentada ao Programa de PósGraduação em Reprodução Animal da Faculdade de Medicina Veterinária e Zootecnia da Universidade de São Paulo para obtenção do título de Doutor em Ciências

Departamento:

Reprodução Animal

Área de Concentração:

Reprodução Animal

Orientador:

Prof. Dr. Marcelo Alcindo de Barros Vaz Guimarães

São Paulo 
Autorizo a reprodução parcial ou total desta obra, para fins acadêmicos, desde que citada a fonte.

DADOS INTERNACIONAIS DE CATALOGAÇÃO-NA-PUBLICAÇÃo

(Biblioteca Virginie Buff D’Ápice da Faculdade de Medicina Veterinária e Zootecnia da Universidade de São Paulo)

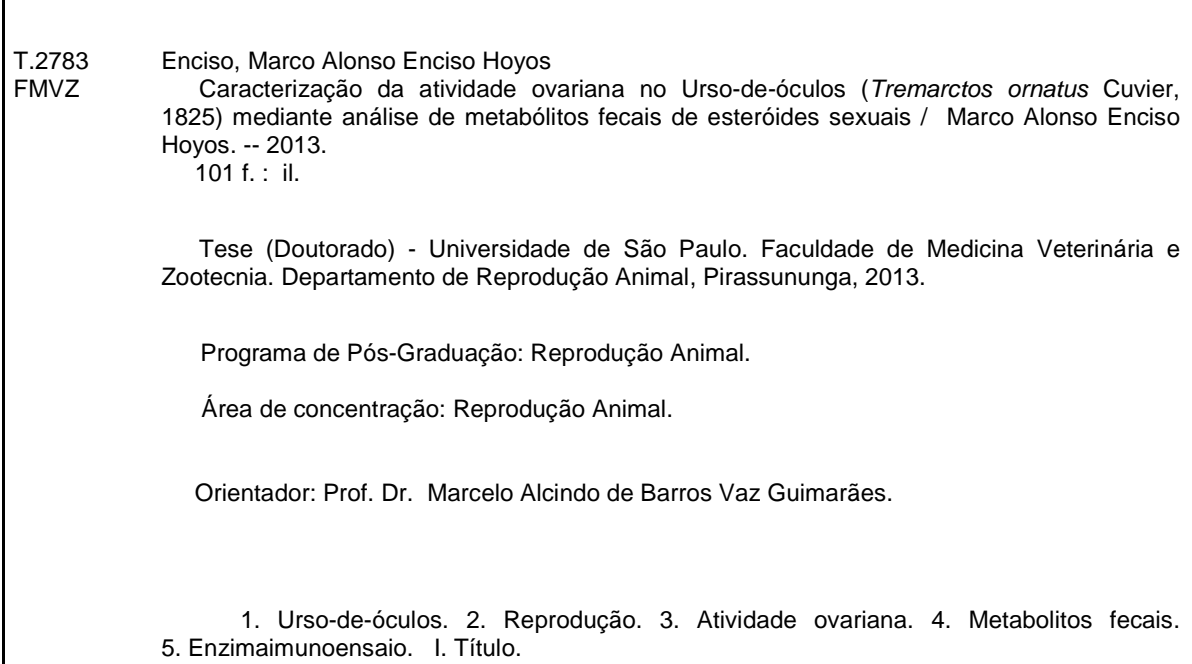

1. Urso-de-óculos. 2. Reprodução. 3. Atividade ovariana. 4. Metabolitos fecais. 5. Enzimaimunoensaio. I. Título. 


\section{FACULDADE DE MEDICINA VETERINÁRIA E ZOOTECNIA}

\section{Comissão de Ética no uso de animais}

\section{CERTIFICADO}

Certificamos que o Projeto intitulado "Caracterização da atividade ovariana na fêmea de Urso-de-Óculos (Tremarctos ornatus CUVIER, 1825) mediante análise de metabólitos fecais de esteróides sexuais", protocolado sob o n ${ }^{\circ} 2225 / 2011$, utilizando 6 (seis) ursos-de-óculos, sob a responsabilidade do(a) Prof. Dr. Marcelo Alcindo de Barros Vaz Guimarães, está de acordo com os princípios éticos de experimentação animal da "Comissão de Ética no uso de animais" da Faculdade de Medicina Veterinária e Zootecnia da Universidade de São Paulo e foi aprovado em reunião de $22 / 6 / 2011$.

We certify that the Research "Characterization of the ovarian activity in the female spectacled bear (Tremarctos ornatus CUVIER, 1825) using faecal metabolites analysis of sexual steroids", protocol number 2225/2011, utilizing 6 (six) spectacled bears, under the responsibility Prof. Dr. Marcelo Alcindo de Barros Vaz Guimarães, agree with Ethical Principles in Animal Research adopted by "Ethic Committee in the use of animals" of the School of Veterinary Medicine and Animal Science of University of São Paulo and was approved in the meeting of day 06/22/2011.

São Paulo, 27 de junho de 2011.

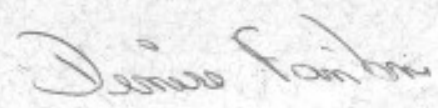

Profa. Dra. Denise Tabacchi Fantoni Presidente 


\section{FOLHA DE AVLIAÇÃO}

Nome: ENCISO HOYOS, Marco Alonso

Título: Caracterização da atividade ovariana no Urso-de-óculos (Tremarctos ornatus Cuvier, 1825) mediante análise de metabólitos fecais de esteróides sexuais

Tese apresentada ao Programa de PósGraduação em Reprodução Animal da Faculdade de Medicina Veterinária e Zootecnia da Universidade de São Paulo para obtenção do título de Doutor em Ciências

Data:

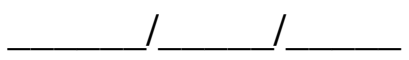

Banca Examinadora

Prof. Dr.

Instituição:

Julgamento:

Prof. Dr.

Instituição:

Julgamento:

Prof. Dr.

Instituição:

Julgamento:

Prof. Dr.

Instituição:

Julgamento:

Prof. Dr.

Instituição:

Julgamento: 
Dedico este trabalho...

A Deus

Ao meu filho Salvador, por existir, por ser o melhor presente que poderia ter recebido na vida

A minha esposa, Yuliana, pela paciência e compreensão

A minha mãe, Carmen Rosa, por todo o amor, confiança e incentivo para continuar com os meus projetos, e a meu pai Teodosio, por cuidar de mim desde o céu

Ao meu orientador, Marcelo, por suportar a minha maneira de fazer as coisas, por me entender, por se comportar como um amigo, mais que um chefe

Aos meus amigos peruanos e brasileiros, que me apoiaram e compartilharam momentos das suas vidas comigo, durante este longo caminho

...e finalmente a uma espécie que me deu a possibilidade de pesquisar

a partir da graduação, o bicho que mais amo, obrigado Oso de Anteojos! 


\section{Agradecimentos}

- A Universidade de São Paulo (USP) e ao Departamento de Reprodução Animal (VRA) da FMVZ, especialmente ao Prof. Dr. Marcelo Alcindo de Barros Vaz Guimarães pela grande oportunidade.

- Ao Conselho Nacional de Desenvolvimento Científico e Tecnológico (CNPq) pela bolsa concedida.

- A Lizette Bermúdez, Curadora geral do Parque Zoológico Huachipa, pelo apoio incondicional, por compartir o mesmo interesse científico, e principalmente pela amizade e confiança depositadas.

- Aos tratadores do Parque Zoológico Huachipa, senhores Porfirio Aguilar, Luis Ramos e Cátedro Montes, que ajudaram na coleta de amostras com muita eficiência.

- A Gianmarco Rojas, veterinário do Parque Zoológico Huachipa, que colaborou com a aplicação dos hormônios e pelas fotografias cedidas.

- A Tatiana Quevedo, ex-chefa da División de Zoología do Patronato del Parque de Las Leyendas "Felipe Benavides Barreda", que colaborou desinteressadamente com o projeto.

- Aos tratadores do Patronato del Parque de Las Leyendas "Felipe Benavides Barreda", senhores Samy Mejía e Alfredo Puell que ajudaram na coleta de amostras.

- À Dirección General Forestal y de Fauna Silvestre (DGFFS) do Ministério de Agricultura (MINAG) do Peru, pelas autorizações de pesquisa concedidas com muita rapidez, em especial a Elisa Ruiz.

- Ao Prof. Dr. Wilfredo Huanca López, chefe do Laboratório de Reprodução Animal da Facultad de Medicina Veterinaria, Universidad Nacional Mayor de San Marcos (UNMSM), por me permitir usar o laboratório para as extrações, como nos tempos da graduação.

- Ao Prof. Dr. Rupert Palme, do Instituto de Bioquímica Médica, Veterinärmedizinische Universität Wien-Áustria, pela colaboração no processamento das amostras dos metabólitos.

- A Judith Figueroa, da Asociación para la Investigación y Conservación de la Biodiversidad (AICB), por ceder fotos das ursas, e pela inspiração para trabalhar com o Urso-de-óculos desde o ano 2004!, Obrigado!.

- A Rob Foddering e Alice Ralph de Wired Canvas ${ }^{\odot}$ (Londres), pela cessão do desenho do Urso "com óculos".

- A Luis Llanco e Omar Gonzales-Viera, peruanos e uspianos, pela amizade e pelo apoio logístico durante estes quase quatro anos de convivência em São Paulo.

- Finalmente, um grande agradecimento a Harumi Doi Shiraishi, secretária do PPGRA, quem sempre me apoiou para as minhas necessidades e ajudou com toda a burocracia da USP. 


\section{RESUMO}

ENCISO, M. A. Caracterização da atividade ovariana no Urso-de-óculos (Tremarctos ornatus Cuvier, 1825) mediante análise de metabólitos fecais de esteróides sexuais. [Characterization of ovarian activity in Spectacled bear (Tremarctos ornatus Cuvier, 1825) by analysis of fecal metabolites of sex steroids]. 2013. $101 \mathrm{f}$. Tese (Doutorado em Ciências) - Faculdade de Medicina Veterinária e Zootecnia, Universidade de São Paulo, São Paulo, 2013.

O Urso-de-óculos (Tremarctos ornatus), único urso endêmico da América do Sul, é uma espécie severamente ameaçada devido à perda do seu hábitat e à caça. É importante do ponto de vista da conservação pela função que cumpre no ecossistema onde habita e pela sua relação com a cultura Andina. Por estas razões, torna-se necessária a aplicação de alternativas de conservação a espécie. Uma ferramenta alternativa de conservação é a reprodução assistida, porém, existe pouco conhecimento da reprodução desta espécie. A pouca informação sobre os padrões reprodutivos diminui a possibilidade de se estabelecer programas de reprodução bem sucedidos e torna-se mais difícil a criação de planos de conservação. O objetivo deste estudo foi caracterizar o ciclo ovariano na fêmea do Urso-de-óculos. Para tanto foi realizada a monitoração endócrina por meio da extração e dosagem de metabólitos fecais dos esteróides sexuais: estradiol e progesterona. $O$ estudo foi realizado com amostras colhidas de seis fêmeas de $T$. ornatus mantidas em cativeiro em dois zoológicos da cidade de Lima, Peru, pelo período de treze meses, desde Fevereiro de 2010 até Abril de 2011. As extrações dos metabólitos fecais foram feitas no Laboratorio de Reproducción Animal, FMVUNMSM, em Lima, Peru; e foram quantificados por enzimaimunoensaio (EIE), no Instituto de Bioquímica Médica, Veterinärmedizinische Universität Wien-Áustria. Os resultados indicam que é possível descrever e monitorar a endocrinologia do ciclo ovariano em $T$. ornatus de forma não-invasiva através do uso de metabólitos fecais de esteroides sexuais; demonstrando que o Urso-de-óculos em cativeiro é uma espécie que conta com uma reprodução não sazonal, com fase folicular e lútea durando em média 08 e 22 dias, respectivamente. Nestas condições, apresenta em média, de três a quatro fases de atividade ovarianas por ano. Os resultados 
encontrados ajudarão a compreender o ciclo ovariano nos Ursos-de-óculos e facilitar o desenvolvimento de programas de reprodução assistida na espécie.

Palavras-chave: Urso-de-óculos. Reprodução. Atividade Ovariana. Metabolitos fecais. Enzimaimunoensaio. 


\section{ABSTRACT}

ENCISO, M. A. Characterization of ovarian activity in Spectacled bear (Tremarctos ornatus Cuvier, 1825) by analysis of fecal metabolites of sex steroids. [Caracterização da atividade ovariana no Urso-de-óculos (Tremarctos ornatus Cuvier, 1825) mediante análise de metabólitos fecais de esteróides sexuais) mediante análise de metabólitos fecais de esteróides sexuais]. 2013. 101 f. Tese (Doutorado em Ciências) - Faculdade de Medicina Veterinária e Zootecnia, Universidade de São Paulo, São Paulo, 2013.

Spectacled bear (Tremarctos ornatus) is the only bear species that inhabits South America. It is an endangered species due to habitat loss and hunting. For the conservation point of view it is an important species for the ecosystem maintenance and also for their relationship with the Andean culture. For these reasons it is necessary to apply conservation alternatives for this species. Assisted reproduction is an alternative conservation tool; however, there is a lack of knowledge of the Spectacled bear reproduction. Little information about the reproductive parameters diminishes the possibility to establish a successful breeding program and make difficult the implementation of conservation plans for the species. The aim of this study was to characterize the ovarian cycle in the female Spectacled bear with noninvasive techniques for monitoring fecal metabolites of reproductive hormones (estradiol and progesterone). The study was carried out with samples collected by a 13-month period (Feb/10 to April/11), from six captive females $T$. ornatus kept in two zoological institutions in Lima, Peru. The metabolites extraction was carried out at Laboratory of Animal Reproduction, FMV-UNMSM, in Lima-Peru, and the hormonal analysis was performed in the Institute of Medical Biochemistry, Veterinärmedizinische Universität Wien-Austria. The results show us that it is possible to describe and realize a non-invasive monitoring of ovarian cycles in $T$. ornatus, with the use of fecal metabolites of sex steroids; and demonstrates that in captive conditions Spectacled bear is a non-seasonal reproduction species, with follicular and luteal phases lasting on average 8 and 22 days, respectively, whereas in captivity has on average three to four stages of ovarian activity per year. These results will help to understand the ovarian cycle in Spectacled Bear and facilitate the development of programs of assisted reproduction in the species. 
Key words: Spectacled bear. Reproduction. Ovarian activity. Fecal metabolites. Enzyme immunoassay. 


\section{LISTA DE FIGURAS}

Figura 1 - Individuo de Urso-de-óculos (Tremarctos ornatus), no Patronato Parque de Las Leyendas "Felipe Benavides Barreda" (PATPAL)

-- Lima - Peru - 2011 .................................................

Figura 2 - Mapa de distribuição do Urso-de-óculos (Tremarctos ornatus). ....26

Figura 3 - Dieta do Urso-de-óculos na natureza na região de Amazonas, nordeste do Peru. Restos frescos de comida, A. Puya sp., B. Tillandsia sp.

Figura 4 - As fêmeas utilizadas no estudo. A. Candy, B. Susy, C. Luna, D. Estrella, E. Hana, F. Petsi.

Figura 5 - Recintos de exibição das fêmeas de Urso-de-óculos. A. Parque Zoológico Huachipa, B. Patronato Parque de Las Leyendas "Felipe Benavides Barreda".

Figura 6 - Aplicação do hormônio para a validação fisiológica/indução de ovulação. A. O produto aplicado, Gestran Plus ${ }^{\circledR}$ (Tecnopec, São Paulo, Brasil). B. Lançamento do dardo mediante zarabatana.. 


\section{LISTA DE GRÁFICOS}

Gráfico 1 - Concentrações dos metabólitos fecais de estradiol (E-A) e progesterona (PDG) na fêmea Hana no desafio de análogo de GnRH para validação fisiológica...................................................62

Gráfico 2 - Concentrações dos metabólitos fecais de estradiol (E-A) e progesterona (PDG) na fêmea Petsi no desafio de análogo de GnRH para validação fisiológica.

Gráfico 3 - Perfis das concentrações de metabólitos fecais de estradiol (EA) e progesterona (PDG) nas duas fêmeas do $\mathrm{PZH}$, desde Março de 2010 a Março de 2011

Gráfico 4 - Perfis das concentrações de metabólitos fecais de estradiol (EA) e progesterona (PDG) nas quatro fêmeas do PATPAL, desde Fevereiro de 2010 a Fevereiro de 2011.

Gráfico 5 - Concentrações médias e erros-padrão consolidados por mês dos metabólitos fecais de estradiol (E-A) e progesterona (PDG) nas fêmeas do $\mathrm{PZH}$.

Gráfico 6 - Concentrações médias e erros-padrão consolidados por mês dos metabólitos fecais de estradiol (E-A) e progesterona (PDG) nas fêmeas Susy e Luna do PATPAL...............................................75

Gráfico 7 - Concentrações médias e erros-padrão consolidados por mês dos metabólitos fecais de estradiol (E-A) e progesterona (PDG) nas fêmeas Estrella e Candy do PATPAL

Gráfico 8 - Concentrações médias e erros-padrão consolidados por estações do ano dos metabólitos fecais de estradiol (E-A) e progesterona (PDG) nas seis fêmeas estudadas. 


\section{LISTA DE TABELAS}

Tabela 1 - Identificação e idade estimada das fêmeas utilizadas no estudo.. .....48

Tabela 2 - Total de amostras de fezes colhidas durante o período de

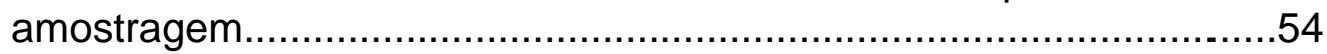




\section{SUMÁRIO}

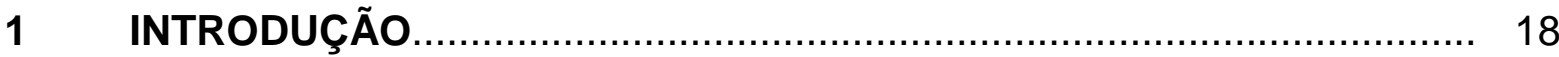

2 REVISÃO DA LITERATURA ............................................................. 23

2.1 Aspectos biológicos do Urso-de-óculos Tremarctos ornatus..................... 23

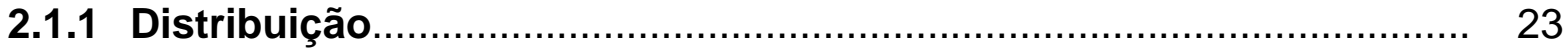

2.1.2 Características físicas.................................................................. 24

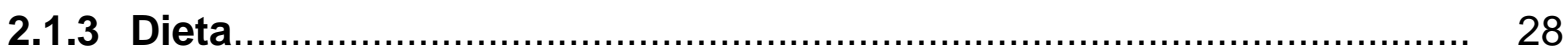

2.1.4 Organização e comportamento social............................................. 30

2.1.5 Estado de conservação............................................................... 33

2.1.6 Ecología e biologia reprodutiva ...................................................... 35

2.2 Métodos não invasivos..................................................................... 38

2.3 Metodologías analíticas.................................................................. 40

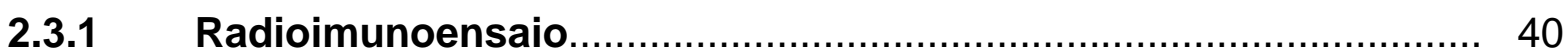

2.3.2 Enzimaimunoensaio ........................................................... 41

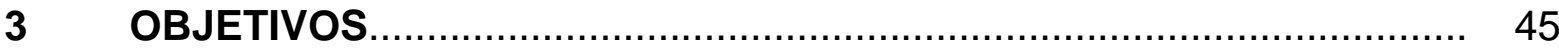

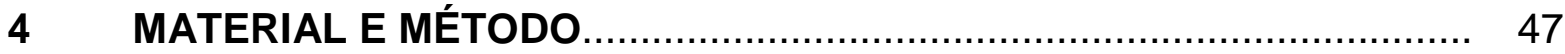

4.1 Animais e Instalações experimentais.................................................. 47

4.2 Validação fisiológica/Indução de ovulação.............................................. 50

4.3 Validação biológica................................................................... 53

4.4 Colheita e armazenamento das amostras............................................ 53

4.5 Processamento das amostras: extração................................................ 54

4.6 Dosagens e análises hormonais por Enzimaimonoensaio (EIE)...... 55

4.6.1 Transformação das concentrações determinadas por EIE................. 57

4.7 Validação laboratorial.................................................................... 57 


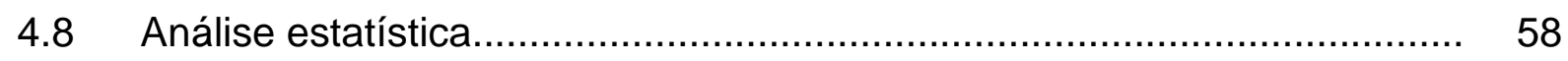

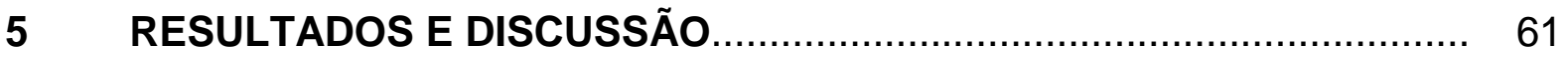

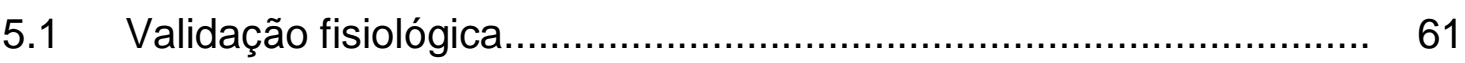

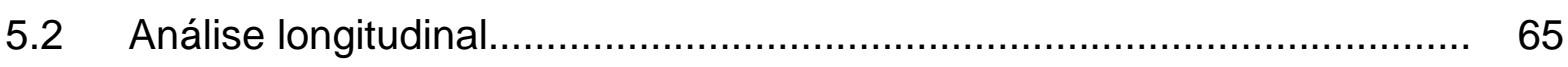

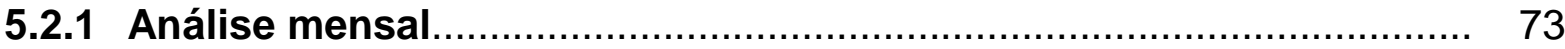

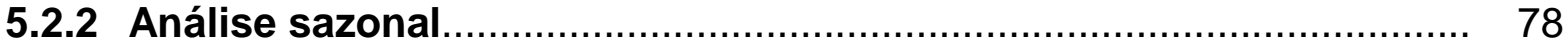

5.3 Considerações finais...................................................................... 82

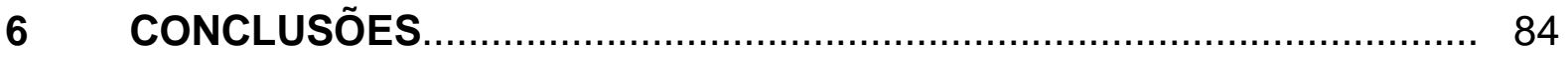

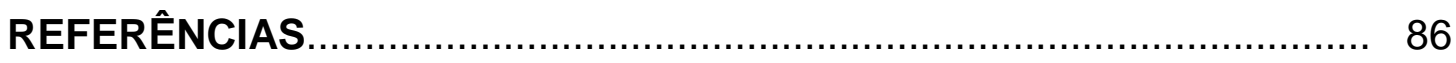

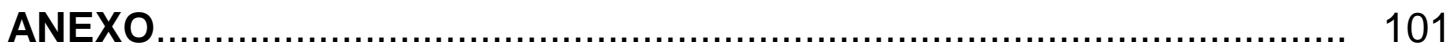





\section{INTRODUÇÃO}

A extinção de espécies de mamíferos é parte de um processo natural que é irreversível, mas vem acontecendo num ritmo acelerado por causa da intervenção humana e suas atividades, tais como a destruição do hábitat, a caça furtiva, e a competição com espécies introduzidas (HOLT; PICKARD, 1999).

O risco de extinção das espécies é ilustrado pela Lista Vermelha (Red List), lançada pelo Comité de Supervivência das Espécies (Species Survival Commission, SSC) da IUCN (União Internacional para a Conservação da Natureza) (IUCN, 2012a). Este documento cataloga cerca de 1.530 espécies de animais relatados como criticamente ameaçadas, incluindo 162 espécies de mamíferos. Este relatório também classifica 70 espécies de mamíferos como completamente eliminados nos últimos anos e outras espécies como extintas em seu habitat natural, com possibilidades de recuperação das suas populações através de programas de conservação ex situ. A Lista Vermelha obedece a critérios precisos, para avaliar os riscos de extinção de milhares das espécies e subespécies em todas as regiões do mundo, com o objetivo de informar sobre a urgência das medidas de conservação para o público e legisladores, além de ser de ajuda à comunidade internacional na tentativa de reduzir as extinções. Assim, dentre as múltiplas classificações, aquelas que representam categorias de ameaça, são: Vulnerável (VU), considerada como estando a sofrer um risco elevado de extinção na natureza; Em perigo (EN), considerada como estando a sofrer um risco muito elevado de extinção na natureza; e Em perigo crítico (CR), considerada como estando a sofrer um risco extremamente elevado de extinção na natureza (IUCN, 2012b). 
O objetivo da conservação das espécies animais é manter a biodiversidade, pois a remoção de uma única espécie pode afetar o funcionamento dos ecossistemas globais (MARGULES; PRESSEY, 2000; MYERS et al., 2000), sendo a preservação do hábitat uma das melhores maneiras de conservar esta biodiversidade (WILDT et al., 1997). A propagação de uma população, ainda que restrita, também faz parte de uma abordagem multi-disciplinar para a conservação, incluindo caracterizações genéticas e ecológicas e outras estratégias (COMIZZOLI et al., 2000). As estratégias de conservação in situ permitem que populações de animais vivos sejam mantidas em seus ambientes naturais. No entanto, estes esforços são muitas vezes insuficientes para a propagação de pequenas populações e a manutenção da diversidade genética adequada. Assim, novas estratégias de conservação ex situ foram desenvolvidas, visando estabelecer populações viáveis através do uso das técnicas reprodutivas e dos Bancos de Recursos Genômicos, que são ferramentas valiosas para a manutenção da diversidade genética (WILDT, 1992; WILDT et al., 1997; AMSTISLAVSKY; LINDEBERG; LUVONI, 2012).

Porém, não se deve desconsiderar a importância do conhecimento das espécies através da pesquisa básica, que não deve ser deixada de lado apenas por se ter solucionado um problema individual com o uso da biotecnologia, posto que ambas sejam de grande importância para a conservação e preservação das informações genéticas das espécies (THOMPSON, 1993). Muitas vezes é necessário um estudo básico a respeito da biologia das espécies para que se possam utilizar as técnicas disponíveis, porém, é bastante provável e até comum que uma espécie atinja um estágio onde se encontre altamente ameaçada e não se conheça nada a respeito da mesma (WILDT et al., 1995). 
Por exemplo, a análise de metabólitos fecais de hormônios é uma ferramenta de monitoramento não invasivo que permite acessar a atividade reprodutiva e adrenocortical, e tem revolucionado a pesquisa nas espécies ameaçadas (LASLEY; KIRKPATRICK, 1991; BROWN; TERIO; GRAHAM, 1996; BROWN; WILDT, 1997; MILLSPAUGH; WASHBURN, 2004; SCHWARZENBERGER, 2007).

Durante as últimas décadas, o monitoramento de metabólitos de estrógenos e progestágenos nas fezes e urina permitiu a caracterização efetiva do ciclo estral, da gestação e de padrões sazonais na reprodução de varias espécies de carnívoros ameaçadas, tais como felinos (BROWN et al., 1994; BROWN; TERIO; GRAHAM, 1996; VIAU; FELIPPE; OLIVEIRA, 2005; GRAHAM et al., 2006; KINOSHITA et al., 2011) e ursídeos (ISHIKAWA et al., 2002, 2003; ONUMA et al., 2002; SCHWARZENBERGER et al., 2004; DEHNHARD et al., 2006; KERSEY et al., 2010; STOOPS; MACKINNON; ROTH, 2012). No entanto, para muitas destas espécies ainda é necessário o desenvolvimento de novos trabalhos, gerando maior compreensão a respeito da fisiologia reprodutiva nesses animais.

Uma espécie que merece a maior atenção para o desenvolvimento de planos de conservação pela sua situação de ameaça é o Urso-de-óculos (Tremarctos ornatus). É o único urso que habita a América do Sul, e por suas características e importância, é uma espécie que precisa de estudos dirigidos a conhecer sua reprodução, mas a quantidade de informação relacionada com sua fisiologia reprodutiva é bem limitada. Desta forma, o intuito deste estudo foi caracterizar a atividade ovariana da fêmea de $T$. ornatus mediante uma análise não invasiva de metabólitos de esteroides sexuais presentes nas fezes. O projeto foi executado no Departamento de Reprodução Animal (VRA) da Faculdade de Medicina Veterinária e Zootecnia da Universidade de São Paulo - Brasil, em parceria com o Laboratório de 
Reprodução Animal da Faculdade de Medicina Veterinária da Universidad Nacional Mayor de San Marcos - Peru e o Instituto de Bioquímica Médica, Veterinärmedizinische Universität Wien - Áustria, com amostras colhidas em dois zoológicos da cidade de Lima, Peru. 



\section{REVISÃO DA LITERATURA}

2.1 Aspectos biológicos do Urso-de-óculos Tremarctos ornatus

A Ursidae é uma das famílias mais ameaçadas dentro da ordem Carnívora. As oito espécies que compõem a família estão enfrentando uma perda de habitat muito extensiva, além de uma intensa perseguição humana (SCHIPPER et al., 2008). A falta de informações sobre as espécies de ursos tropicais, como o Urso-deóculos (Figura 1), tem sido um obstáculo para a sua conservação em longo prazo, mas os esforços para preencher vazios no conhecimento da espécie estão aumentando (GARCÍA-RANGEL, 2012).

\subsubsection{Distribuição}

O Urso-de-óculos ou Urso Andino (Tremarctos ornatus Cuvier, 1825) é o único representante da família Ursidae que habita a região Andina da América do Sul. Esta espécie ocupa uma grande variedade de hábitats, como o deserto litorâneo peruano, desde os $200 \mathrm{~m}$ de altitude até o páramo e a puna, ecossistemas das terras altas dos Andes, e na zona nevada, acima dos $4.750 \mathrm{~m}$ de altitude (PEYTON, 1980, 1999; PAISLEY, 2001). A distribuição de T. ornatus (Figura 2) abrange as três cadeias que compõem a Cordilheira dos Andes (lado leste, central e oeste), e vai desde o norte de Venezuela, até o sul da Bolívia, com possibilidades de ocorrência 
desde as serras do Darién em Panamá (GOLDSTEIN et al., 2008a) até o norte da Argentina, na região de Salta (DEL MORAL; BRACHO, 2009), mas tanto a existência histórica e atual das populações de ursos residentes é inconclusiva no primeiro ponto e controversa no segundo. O Peru é o país que conta aparentemente com uma das maiores populações de Urso-de-óculos, segundo cálculos baseados no território de ocupação da espécie, com estimativas de ao redor de 5.750 indivíduos em vida livre (PEYTON, 1999), número este decrescente, de acordo com as apreciações dos especialistas que trabalham em campo no Peru (JIMENEZ et al., 2010; MINAM, 2011).

\subsubsection{Características físicas}

Em comparação com as outras espécies de ursos, o Urso-de-óculos é considerado de tamanho médio, medindo entre 1,5 e 2 m de comprimento da cabeça à cauda, e pesando entre 60 e $175 \mathrm{~kg}$. As fêmeas apresentam geralmente 2/3 do tamanho do macho. Sua pelagem é geralmente preta, mas pode variar de marrom até vermelho escuro (MONDOLFI, 1971; PEYTON, 1980; EMMONS; FEER, 1999; GARCÍA-RANGEL, 2012). Na sua face e na região peitoral apresenta uma marcação específica que se assemelha a uma máscara ou óculos de cor branca ou creme, que Ihe deu o nome comum de Urso-de-óculos. Todos os $T$. ornatus tem essa cor, mas cada padrão de marcação é individual e única, como uma impressão digital, porém, foram também descritos indivíduos que carecem dessa marcação (FIGUEROA; STUCCHI, 2009; GARCÍA-RANGEL, 2012). 
Figura 1 - Individuo de Urso-de-óculos (Tremarctos ornatus), no Patronato Parque de Las Leyendas "Felipe Benavides Barreda" (PATPAL), Lima - Peru, 2011

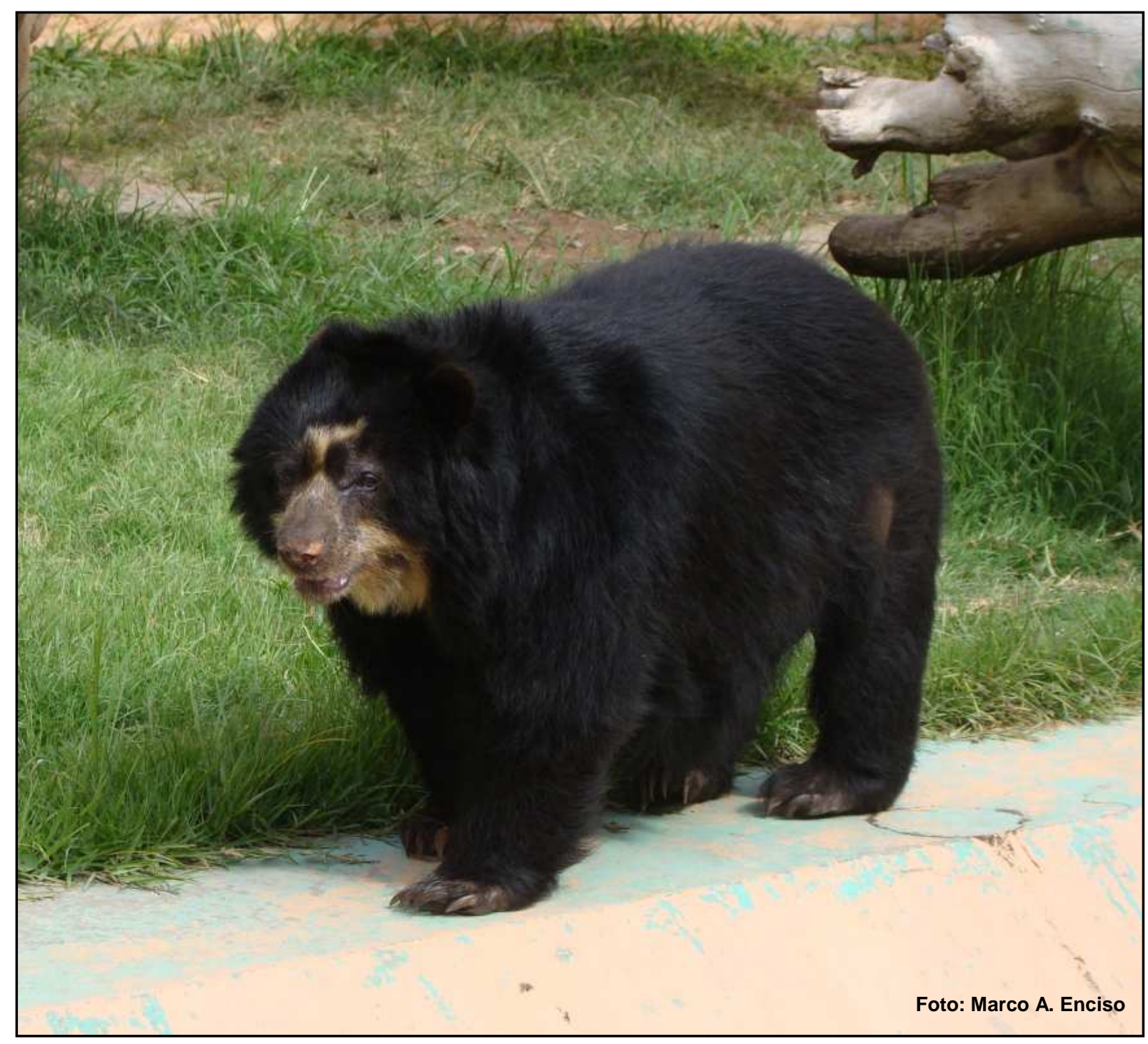


Figura 2 - Mapa de distribuição do Urso-de-óculos (Tremarctos ornatus)

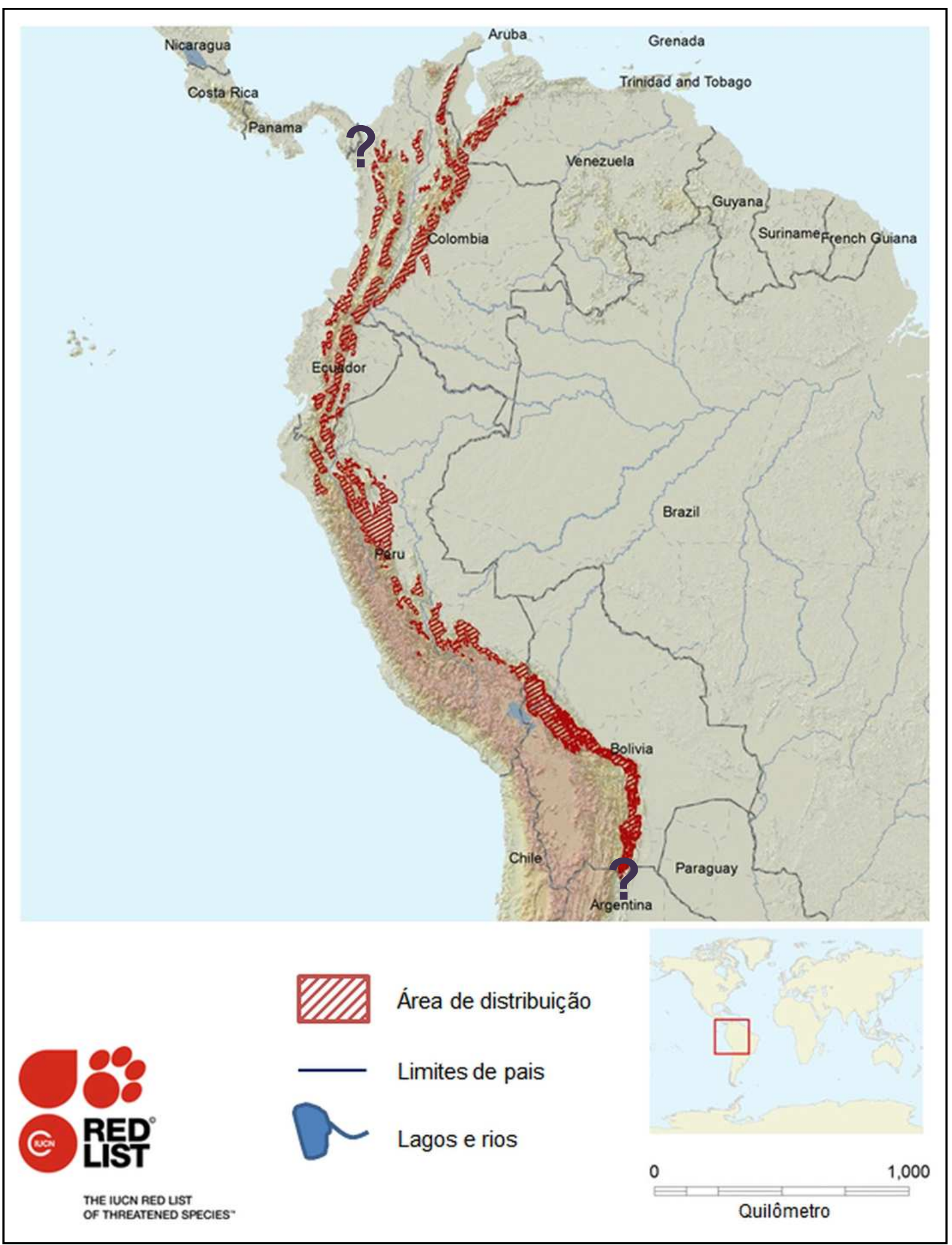

Fonte: Adaptado do mapa da Lista Vermelha da IUCN (GOLDSTEIN et al, 2008b). O símbolo "?" representa os pontos incertos de distribuição em Panamá e na Argentina (GARCÍA-RANGEL, 2012) 
Como em todas as espécies de ursos, os Urso-de-óculos são plantígrados e seus membros dianteiros são mais cumpridos que os traseiros, o que os ajuda a subir nas árvores, comportamento conhecido para esta espécie. O Urso-de-óculos tem o corpo roliço e a cauda curta, a qual muitas vezes permanece escondida na pele, o pescoço é curto e grosso, pequenas orelhas arredondadas e tem o focinho mais curto em comparação com os demais ursídeos (MONDOLFI, 1971; PEYTON, 1980).

Os Tremarctos ornatus são também distinguidos por ter o maior músculo zigomático mandibular em proporção ao tamanho do corpo, entre os demais ursos. Estas duas últimas características são compartilhadas com o Panda gigante (Ailuropoda melanoleuca), e permitem ao Urso-de-óculos moer alimentos fibrosos difíceis, garantindo seu nicho alimentar contra os concorrentes. Ao contrário dos ursos do gênero Ursus, cujo quarto pré-molar tem um protocono mais desenvolvido como adaptação para cortar carne (KURTÉN, 1966), o quarto pré-molar do Urso-deóculos tem cúspides despontadas (como o resto de molares e pré-molares), tem três cavidades pulpares em vez de dois, e pode ter três raízes, em vez das duas que caracterizam aos ursos do gênero Ursus (THENIUS, 1976). Os músculos mastigatórios e os dentes tem a característica de estar projetados para suportar as tensões de britagem e moagem das plantas; assim, é muito provável que o Urso-deóculos seja a espécie de urso mais herbívora de todas (SACCO; VAN VALKENBURGH, 2004; CHRISTIANSEN, 2008). 


\subsubsection{Dieta}

Embora classificado como um carnívoro, o Urso-de-óculos possui principalmente hábitos vegetarianos. Os estudos de campo consideram a espécie como onívora - herbívora, e sua dieta inclui diversos tipos de materiais vegetais, frutas e carne. Na maior parte de sua distribuição são de particular importância na dieta às partes suculentas das plantas da família Bromeliaceae, tanto epífitas como terrestres. Nos ervaçais, o coração das plantas do gênero Puya (Figura 3) é um alimento muito importante, já que são as únicas bromélias abundantes e disponíveis na maior parte do ano (FIGUEROA; STUCCHI, 2008; ENCISO; GÁLVEZ-ROEDER; LA TORRE, 2012).

Nas florestas o Urso-de-óculos sobe nas árvores para obter Tillandsia spp., bromélias epífitas, das quais comem o tecido meristemático basal e descartam aquelas peças restantes para o chão da floresta (Figura 3). Eles selecionam zonas ou árvores que tem uma alta densidade de bromélias grandes. As bromélias compõem de 15 a $90 \%$ da sua dieta, aproximadamente, e isto vai depender da época ou da estação do ano e da área geográfica. Os frutos constituem a outra parte da dieta, variando inversamente às bromélias. Tanto os frutos dos arbustos e das árvores são consumidos (das famílias Lauraceae, Moraceae, Ericaceae, Euphorbiaceae). Outros alimentos incluem pecíolos de palma, brotos de bambu, bulbos de orquídeas, e em habitats mais secos, como o deserto litorâneo do Peru, eles comem as frutas e polpa dos cactos, além da casca da árvore Pasallo (Bombax discolor) (PEYTON, 1987a; FIGUEROA; STUCCHI, 2008). 
Figura 3 - Dieta do Urso-de-óculos na natureza na região de Amazonas, nordeste do Peru. Restos frescos de comida, A. Puya sp., B. Tillandsia sp.

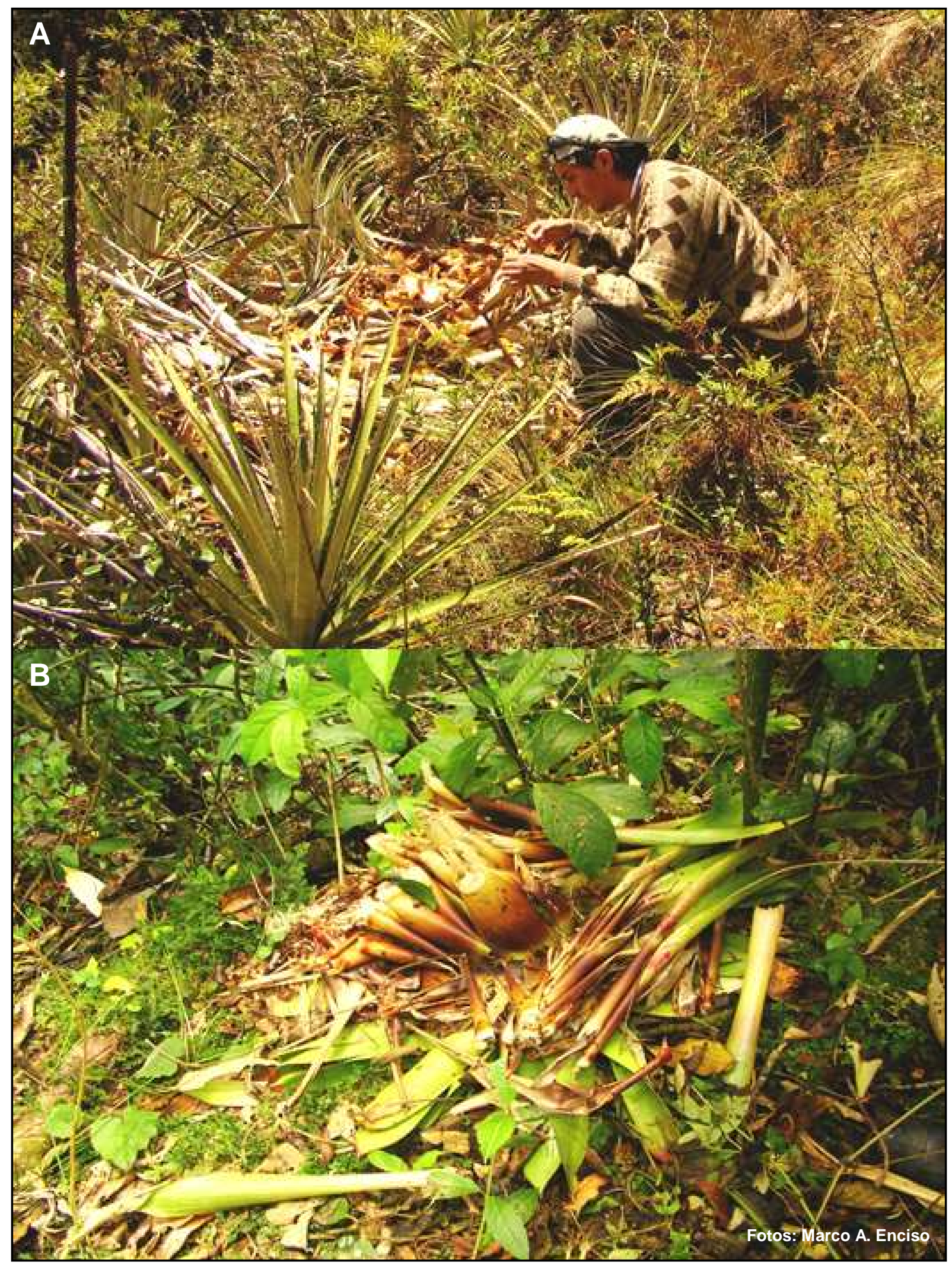


Quando o Urso-de-óculos está perto de assentamentos humanos, usualmente se aventura em campos de cultura de milho, além disso, a carne animal é outro alimento potencialmente importante, embora nunca um grande componente na dieta. Eles também comem insetos, tais como larvas de besouros, abelhas e minhocas; caracóis, pequenos mamíferos, como a Paca (Cuniculus spp.), aves, e ocasionalmente, mamíferos grandes, como veados e gado bovino que se encontra em pastoreio e desprotegido (SUÁREZ, 1989; FIGUEROA; STUCCHI, 2009). Existe uma ampla controvérsia se a carne que eles consomem vem de animais que eles mesmos caçam, ou se vem de animais mortos por outros predadores. Quando se alimentam de carcaças de bovinos, a que pode levar vários dias para ser consumida, muitas vezes constroem ninhos no solo e nas árvores para descansar (GARSHELIS, 2009). A espécie é muito importante na dinâmica da floresta e da vegetação do deserto, já que é um dispersor de sementes (PEYTON, 1987b; FIGUEROA; STUCCHI, 2008).

\subsubsection{Organização e comportamento social}

Os Ursos-de-óculos são geralmente solitários, no entanto, têm sido relatados por agricultores e caçadores grupos de até nove indivíduos que se alimentam em matas do cacto Opuntia sp., bem como em campos de cultura de milho. Existem relatos de filhotes que costumam ficar com a mãe até mais de um ano após o nascimento (PEYTON, 1999). 
De acordo com Castellanos (2005), as fêmeas têm áreas de vida menores que os machos; e também pode existir uma grande sobreposição entre as áreas de vida, especialmente entre fêmeas e machos (CASTELLANOS; ALTAMIRANO; TAPIA, 2001; PAISLEY, 2001; CASTELLANOS, 2005). Paisley (2001) relatou que a área média percorrida pelos ursos por dia é no mínimo de 800 m, sendo a máxima, maior de $6 \mathrm{~km}$ (até $2.435 \mathrm{~m}$ em linha reta), enquanto outros pesquisadores encontraram áreas percorridas por dia que variaram de 3 a 4 km $(1,5 \mathrm{~km}$ em linha reta) (CASTELLANOS; ALTAMIRANO; TAPIA, 2001; GARCÍA-RANGEL, 2012). Movimentos mais longos e áreas de vida maiores têm sido relatados durante a estação chuvosa, de Novembro a Março (PAISLEY, 2001). Ao contrário de outras espécies de ursos, os Ursos-de-óculos não hibernam (PEYTON, 1999; GARSHELIS, 2009). Eles são principalmente diurnos: a atividade geralmente começa em torno das 06 horas da manhã, atinge um patamar entre as 09 e 18 horas e cai progressivamente depois. No entanto é relatado que os padrões de atividade, podem variar de acordo as estações do ano e entre os diferentes locais de estudo, por exemplo, os Ursos-de-óculos são ativos tanto à noite como o dia na floresta de neblina, e no deserto do Peru, eles se refugiam para dormir em horas do meio-dia, provavelmente aguardando a diminuição da temperatura ambiental (PEYTON, 1999; CASTELLANOS; ALTAMIRANO; TAPIA, 2001; PAISLEY, 2001; CASTELLANOS, 2005; FIGUEROA; STUCCHI, 2009).

De acordo com os dados obtidos de indivíduos reintroduzidos, os Ursos-deóculos empregam cerca de $70 \%$ do seu tempo de atividade diária para dedicar-se à alimentação, isto é semelhante ao que foi relatado nos outros membros da família Ursidae (CASTELLANOS; ALTAMIRANO; TAPIA, 2001; GARSHELIS, 2009). 
Os Ursos-de-óculos no interior da floresta são capazes de subir árvores com diâmetros iguais ao comprimento dos seus dois membros dianteiros para acessar a frutos existentes em outras árvores com diâmetros muito maiores. No dossel da floresta onde não é capaz de subir porque as árvores não suportam o peso do animal, o Urso-de-óculos usa a estratégia de forrageio destrutiva que resulta na criação de plataformas de ramos dobrados que têm sido descritos como ninhos (PEYTON, 1987a). As riscas repetitivas dos ursos escaladores nas árvores frutíferas, além da presença de excrementos e a construção de camas em troncos inclinados e ramos, evidencia a considerável atividade do Urso-de-óculos nas árvores (BROWN; RUMIZ, 1989; PEYTON, 1999).

O olfato é o sentido dominante nesta espécie. Quando perturbados durante o dia em um dormitório, os Ursos-de-óculos dão muitos passos em diferentes direções a partir de um ponto à qual retornam depois, para procurar terrenos acidentados para fugir. Os especialistas sugerem que a visão também tem um papel importante ao considerar as mordidas e arranhões deixados pelos ursos em nas caras de árvores que enfrentam as entradas de trilhas perto de fontes de concentração de fruta ou outro alimento. Estes sinais podem alertar sobre a posse de território. $\mathrm{O}$ nome comum "Ukuku", na língua Quéchua, quando ele é dito lentamente aproximase a uma vocalização feita pelo Urso-de-óculos. Tem sido postulado que os trinados de tom grave e agudo produzido pelo Ursos-de-óculos em cativeiro têm a função de manter unidos mães e seus filhotes (PEYTON, 1999). 


\subsubsection{Estado de conservação}

A nível internacional, o Urso-de-óculos está classificado pela Lista Vermelha da União Internacional para a Conservação da Natureza (IUCN) como uma espécie Vulnerável (VU A4cd) (GOLDSTEIN et al., 2008), e segundo a Convenção sobre o Comercio Internacional de Espécies Ameaçadas de Fauna e Flora Silvestres (CITES), o T. ornatus se encontra no Apêndice I, onde se consideram as espécies com maior risco de extinção (CITES, 2009). Na legislação peruana, o Urso-de-óculos está classificado pela Dirección General Forestal y de Fauna Silvestre (DGFFS) como uma espécie Em perigo (FIGUEROA, 2003; MINAM, 2011).

A situação de ameaça para o Urso-de-óculos é devido aos seguintes fatores:

i) A destruição e fragmentação do seu habitat, causada pelo avanço da atividade agrícola, pecuária e indústria mineira nos diferentes ecossistemas de desenvolvimento da espécie (PEYTON, 1999; PAISLEY, 2001; FIGUEROA; STUCCHI, 2009; GARCÍA-RANGEL, 2012),

ii) A caça, que acontece pelo aproveitamento das partes do urso (gordura, sangue, bílis, couro, ossos e garras) para comercialização com fins "curativos" e religiosos (VARGAS, 1997; ROJAS-VERAPINTO; GÁLVEZ-ROEDER; ENCISO, 2010) e

iii) A interação com o homem, devido à aparição dos animais nas áreas agrícolas de cultura de milho e aos ataques ao gado bovino doméstico (PEYTON, 1980; FIGUEROA; STUCCHI, 2002; GOLDSTEIN et al., 2006; FIGUEROA; STUCCHI, 2009; GARCIA-RANGEL, 2012). 
O Urso-de-óculos é uma espécie importante desde o ponto de vista da conservação dos Andes, sendo considerada uma "espécie bandeira" pela função que cumpre no ecossistema onde habita, já que contribui na manutenção, recuperação e expansão da floresta mediante a dispersão de sementes (PEYTON, 1987b) e indiretamente com a manutenção das fontes de recursos hídricos, graças à manutenção da mata nas nascentes dos rios (PEYTON, 1999; VELA et al., 2011).

Além disso, é também importante por sua relação com a cultura e sociedade Andina, onde é objeto de muitas crenças, associadas à melhora da qualidade de vida. Na mitologia pré-colombiana, o Urso-de-óculos foi reverenciado como um grande mediador pelo qual as pessoas e os seus desafios passavam de uma condição para outra, um papel que, sem dúvida, resultou da amplitude da sua distribuição geográfica (por exemplo, entre as forças das trevas que habitam na floresta amazônica e o mundo iluminado dos picos das montanhas mais altas dos Andes, entre o bem e mal, entre saúde e doença, morte e renascimento, entre colheita e semeadura e assim de um ano para o outro) (RANDALL, 1982).

Embora o aumento da concorrência pelos recursos entre o urso e as pessoas, e a adoção da cultura ocidental espanhola, substituíram grande parte dos temores espirituais que os usuários da terra tinham pelo Urso-de-óculos por valores do machismo. Ainda existem vestígios dessas crenças antigas ao longo da área de distribuição da espécie, principalmente na Colômbia, sul do Peru e norte da Bolívia. Qualquer pessoa que se identifique com o Urso-de-óculos através da sua humildade ou machismo, obtém a força desta espécie para começar a lutar contra sua condição socioeconômica em deterioração. Com a extinção do Urso-de-óculos em estado silvestre, morrerá um pouco da esperança para o ser humano (PEYTON, 1999; VARGAS, 2007). 


\subsubsection{Ecologia e biologia reprodutiva}

A maioria das informações sobre a reprodução do Urso-de-óculos foi obtida a partir de animais em cativeiro (BLOXAM, 1977; BROWN; RUMIZ, 1989; PEYTON, 1999; GARCÍA-RANGEL, 2012). Os estudos sugerem que a espécie é poliéstrica, e, como as demais espécies de ursos, pode ter uma reprodução sazonal facultativa (PEYTON, 1999; SPADY; LINDBURG; DURRANT, 2007; GARCÍA-RANGEL, 2012).

$\mathrm{Na}$ natureza, segundo os estudos, o Urso-de-óculos tem atividade reprodutiva todo o ano, com um marcante padrão reprodutivo na época de amadurecimento dos frutos, entre os meses de Março até Outubro, que corresponde às estações de Outono, Inverno e começo da Primavera, sendo a maior atividade de Abril até Junho, no entanto, em animais no cativeiro a reprodução também é contínua, porém, a atividade é concentrada entre os meses de Fevereiro até Setembro, dependendo da latitude do local de cativeiro dos animais (DATHE, 1967; PEYTON, 1980, 1999; BRACHO, 2002, SPADY; LINDBURG; DURRANT, 2007). O período de acasalamento pode durar aproximadamente uma semana, e múltiplas copulas podem ocorrer, sendo o tempo destas ao redor de 12 a 45 minutos (BRACHO, 2002). O cortejo envolve jogos e brigas não agressivas, que podem estar acompanhadas de grunhidos de tom muito alto entre o casal (BLOXAM, 1977).

Como as outras espécies de ursos, o $T$. ornatus é provavelmente capaz de manter uma diapausa embrionária (implantação retardada), como evidenciado pela variabilidade nos períodos de gestação observados em cativeiro, de 150 até 272 dias (BLOXAM, 1977; ROSENTHAL, 1987a, 1988; GARCÍA-RANGEL, 2012). Da mesma forma, esta característica poderia explicar os nascimentos que ocorrem no 
estado silvestre "fora de tempo", mas no momento apropriado para os filhotes ingerirem frutas maduras durante o ano, quando o fenômeno "El Niño", que ocorre em ciclos irregulares cada três a oito anos, altera a fenologia de maturação das espécies vegetais consumidas pela espécie (PEYTON, 1999). Em geral, o parto, tanto em cativeiro quanto na natureza, é relatado a ser mais restrito à sazonalidade quanto o acasalamento (SPADY; LINDBURG; DURRANT, 2007). Os nascimentos na natureza ocorrem normalmente várias semanas antes dos períodos de grande queda de frutos durante a estação chuvosa; esta sincronização permite que os filhotes tenham idade suficiente ara ingerir os frutos maduros, e aproveitar este recurso (PEYTON, 1980). No caso do cativeiro, os nascimentos podem ocorrer durante todo o ano nos zoológicos que se localizam nos países de ocorrência da espécie, enquanto eles estariam mais concentrados principalmente entre os meses de Novembro e Fevereiro (MUELLER, 1989; GARCÍA-RANGEL, 2012); porém, os reportes publicados de nascimentos na América do Sul são muito escassos, só tendo um na Venezuela (GOMÉZ-CASTAÑEDA, 1996) e um no Perú (RÍOS-MEJíA, 2008).

Em cativeiro as ninhadas são compostas de 1-3 filhotes cujos pesos estão na faixa de 300-330 g (DATHE, 1967; BLOXAM, 1977). As ninhadas selvagens geralmente consistem de dois filhotes, embora variem entre um e quatro. Os machos crescem mais rápido do que as fêmeas, e os filhotes recém-nascidos altriciais já mostram a cor e as marcas dos adultos (MONDOLFI, 1971; BLOXAM, 1977; GARSHELIS, 2009). As fêmeas parem numa toca, permanecendo lá por entre três a quatro meses (GARCÍA-RANGEL, 2012). O período de lactação é de um ano e os cuidados maternos são até por dois anos (MONDOLFI, 1971; PAISLEY, 2001, GARCÍA-RANGEL, 2012). Após o desmame, as fêmeas em cativeiro, podem entrar 
em cio dentro das 4-6 semanas, mas isso pode acontecer mais cedo se os filhotes morrem após o nascimento ou forem natimortos (GARCÍA-RANGEL, 2012).

Como em outras espécies de ursos, na natureza a idade da maturidade sexual varia em relação à disponibilidade de alimentos e o peso do animal (PEYTON et al., 1998; HILDERBRAND et al., 1999; RODRÍGUEZ-CLARK; SÁNCHEZMERCADO, 2006; GARSHELIS, 2009), mas em cativeiro a idade da primeira reprodução do $T$. ornatus pode estar entre os 4-7 anos para ambos os sexos (ROSENTHAL, 1987b). O primeiro nascimento ocorre geralmente quando as fêmeas têm cinco anos de idade (ROSENTHAL, 1989). Em cativeiro, a fecundidade da fêmea é consideravelmente menor do que a sua longevidade, enquanto o macho parece manter-se fértil quase toda a sua vida (RODRÍGUEZ-CLARK; SÁNCHEZMERCADO, 2006). Em cativeiro, a média da sobrevivência anual dos recémnascidos é baixa: de $59 \%$ a 64 \% (KOHLER; PRESTON; LACKEY, 2006; RODRÍGUEZ-CLARK; SÁNCHEZ-MERCADO, 2006).

Em relação à endocrinologia reprodutiva do $T$. ornatus, o único relato de análise hormonal na fêmea da espécie foi o realizado pelo Dehnhard et al. (2006), na Alemanha, onde relatam o monitoramento de três fêmeas de Urso-de-óculos mantidas em cativeiro, com o uso da dosagem de metabólitos fecais e urinários de esteroides sexuais. Entretanto, este estudo mostrou-se sem resultados significativos, provavelmente devido ao pequeno número de amostras colhidas, a baixa frequência de colheitas e período estudado curto (uma amostra/animal/semana, durante seis meses); além da ocorrência de prenhes em uma das fêmeas. Os testes realizados não demonstraram concentrações de metabólitos de progesterona que servissem para estabelecer patrões hormonais associados ao ciclo estral (DEHNHARD et al., 2006). 
Segundo Durrant e Spady (2009), nos Estados Unidos, o Instituto para a Conservação e Pesquisa do Zoológico de San Diego (CRES) está desenvolvendo estudos relacionados à fisiologia reprodutiva em várias espécies de ursos (incluindo o Urso-de-óculos), mantidos em cativeiro nos zoológicos das diferentes cidades dos EUA, mas sem dados publicados até o momento (informação verbal) ${ }^{1}$.

\subsection{Métodos não invasivos}

Os métodos convencionais para a obtenção de dados sobre o perfil endócrino em animais domésticos se baseiam na análise de amostras de sangue coletadas sequencialmente. Esta abordagem é muito difícil de realizar na maioria das espécies silvestres, devido às dificuldades de manejo e a susceptibilidade destas espécies ao estresse. Em comparação com os métodos mais tradicionais de análise de hormônios esteroides no sangue, as extrações e dosagens de metabólitos hormonais excretados em urina e fezes são alternativas importantes (BAMBERG et al., 1991; LASLEY: KIRKPATRICK, 1991; BROWN et al., 1994; DEHNHARD et al., 2001; GRAHAM et al., 2001; ZIEGLER; WITTWER, 2005; ABÁIGAR; DOMENÉ; PALOMARES, 2010), sendo que estas técnicas apresentam como principal vantagem o fato de não ser invasivas aos indivíduos pesquisados, e assim não introduzir variáveis que possam alterar os resultados das dosagens. Por conseguinte, em muitos estudos nos quais a amostragem do sangue numa base regular é difícil ou não é possível, como por exemplo, nos estudos sobre animais

\footnotetext{
${ }^{1}$ Informação fornecida por B. Durrant e T. Spady em Escondido/CA (EUA), em Outubro de 2009.
} 
selvagens, ou espécies de pequeno tamanho, muito propensas a estresse, as amostras de fezes tornaram-se um substituto para a análise de hormônios no soro ou plasma. As análises de esteroides fecais foram aplicadas em espécies de vários tamanhos, que vão desde animais tão pequenos como ratos até elefantes ou baleias. (SCHWARZENBERGER et al., 1996; TOUMA; PALME, 2005; SCHWARZENBERGER, 2007).

No caso da análise de metabólitos fecais de progesterona, esta tem sido utilizada com sucesso para monitoramento da função do corpo lúteo e gestação, puberdade e sazonalidade em uma vasta lista de espécies animais, incluindo bovídeos (KIRKPATRICK et al., 1993); primatas (WASSER et al., 1988; HEISTERMANN et al., 1993; SHIDELER et al., 1993; STAVISKY et al., 1995; ZIEGLER et al.; 1996); rinocerontes (SCHWARZENBERGER et al., 1996); felídeos (CZEKALA et al., 1994; BROWN et al., 1994; BORQUE et al., 2005); e ursídeos (ISHIKAWA et al., 2002; ONUMA et al., 2002; SCHWARZENBERGER et al., 2004; KERSEY et al., 2010; STOOPS; MACKINNON; ROTH, 2012).

Segundo Brown et al. (1994), a caracterização da normalidade endócrina é essencial para que aconteça um sucesso reprodutivo, identificando-se quais indivíduos apresentam problemas relativos à fertilidade, e determinando-se o tipo de técnica de reprodução assistida que melhor se aplica em cada espécie. Também é importante lembrar que o metabolismo e excreção de esteroides diferem entre as espécies, sendo que, os métodos não invasivos devem ser rigorosamente validados para cada espécie antes de sua utilização (PALME, 2005).

Os animais mantidos em cativeiro são ideais para o tipo de pesquisa não invasiva, pois permitem uma coleta regular de amostras, facilitando a validação da 
técnica. Uma vez estabelecidas, análises não invasivas de hormônios podem ser aplicadas em estudos que investiguem efeitos, sociais, reprodutivos e ecológicos dos animais em vida livre (LASLEY; KIRKPATRICK, 1991; KIRKPATRICK et al., 1993; MONFORT, 2003; TOUMA; PALME, 2005; SCHWARZENBERGER, 2007).

\subsection{Metodologías analíticas}

Apresentam-se as metodologias analíticas disponíveis para a mensuração de hormônios.

\subsubsection{Radioimunoensaio}

Os princípios da técnica de radioimunoensaio (RIE) foram estabelecidos nos anos 60, o método se baseia no uso de um agente ligante específico e de hormônios radioativos como traçadores, para medir a concentração de substâncias até então imensuráveis pelos métodos bioquímicos disponíveis (THOREL; LARSON, 1978). Segundo os princípios do método, uma quantidade fixa de hormônio radioativo compete com o hormônio a ser medido (idêntico ao radioativo) por um número limitado de sítios de ligação de um agente ligante de alta afinidade e especificidade pelo hormônio em questão. A concentração de um determinado hormônio pode ser quantificada em amostras de fluídos e extratos biológicos (THOREL; LARSON, 1978). 
A maior parte dos conjuntos diagnósticos comerciais disponíveis no mercado foi desenvolvida para avaliação quantitativa de hormônios no soro humano. Os anticorpos destes kits comerciais apresentam uma alta especificidade para a molécula do hormônio, sendo que até podem ser eficientes na detecção dos metabólitos em outras matrizes, se possuírem porcentagem alta de reações cruzadas com estes.

O RIE utiliza material radioativo, o que requer licenças especiais junto aos órgãos reguladores, como a Comissão Nacional de Energia Nuclear (CNEN). Após da dosagem são gerados rejeitos radioativos que devem permanecer armazenados no laboratório por um período de no mínimo 60 dias para o decaimento da vida media do ${ }^{125}$ I, e logo depois possa ser descartado (VIAU, 2007). É importante notar que na atualidade o procedimento de manipulação dos rejeitos radioativos pode-se considerar como um risco para a saúde além de ter pouca praticidade quando comparado com as novas técnicas de mensuração hormonal. Com a chegada de uma maior consciência pela saúde humana e o meio ambiente, foram desenvolvidas alternativas ao RIE para a quantificação hormonal em soro de humano. Assim, aparecem em cena o enzimaimunoensaio (EIE), a quimioluminiscência e a espectometria de massa. Porém, no uso veterinário o EIE vem substituindo gradativamente ao RIE, com grande relevância para os trabalhos com animais silvestres (BORQUE et al., 2005; PEREIRA et al., 2006; SONGSASEN et al., 2006; PETTITT et al., 2007). 


\subsubsection{Enzimaimunoensaio}

As enzimas são os marcadores mais utilizados na atualidade, com as vantagens de não representarem riscos associados à exposição de radioisótopos, bem com a possibilidade da amplificação catalítica e da associação com outros marcadores, como por exemplo, os quimioluminiscentes, resultando em ensaios de baixo limite de detecção (TSUJI et al., 1989; JOHANNSSON, 1991).

O exemplo significativo de enzimaimunoensaio (EIE) heterogêneo é o método que emprega anticorpos imobilizados em placa de poliestireno com número variável de poços de ensaio. Em protocolo clássico, o método é realizado em oito etapas: 1) Ativação da placa, 2) Lavagem, 3) Imobilização dos anticorpos, 4) Lavagem, 5) Incubação, 6) Lavagem, 7) Adição de substrato cromogênico e 8) Leitura óptica dos poços. Este sistema de placas possibilita a realização do ensaio de maneira que garanta a uniformidade de todas as etapas tanto para amostras e referências, condição essencial para confiabilidade dos dados. Outro ponto importante é que devido à alta sensibilidade do método, o mesmo é feito em micro escala o que o torna bastante econômico dado à reduzida quantidade de reagentes utilizados, além da própria rapidez do método (JOHANNSSON, 1991; ZIEGLER; WITTWER, 2005).

Esse sistema de análise pode operar tanto de forma competitiva ou não competitiva. Na forma competitiva, antígenos marcados com enzimas competem com antígenos livres (analito) por número limitado de anticorpos imobilizados. Atualmente utilizam-se, tanto para ensaios competitivos, quanto não-competitivos, sistemas que fazem além da leitura automatizada dos diferentes poços, diluições em série e réplicas das amostras (JOHANNSSON, 1991). 
A maioria dos EIE utiliza anticorpos específicos para hormônios esteroides não metabolizados ou para conjugados de esteroides metabolizados, o que os torna mais aplicáveis para a mensuração de hormônios circulantes no sangue ou metabólitos conjugados na urina e/ou fezes, respectivamente. Entretanto, fezes são mais fáceis de coletar do que soro ou urina, sendo a análise de metabólitos fecais de esteroides o método preferencial para o monitoramento não invasivo da função ovariana em animais selvagens de cativeiro ou de vida livre (CZEKALA et al., 1994; LASLEY; KIRKPATRICK, 1991; MUNRO et al., 1991). Na literatura existem diferentes protocolos de extração hormonal em fezes, sendo que os principais pontos testados nesses protocolos são a utilização de amostras fecais úmidas ou liofilizadas, o tipo de solvente orgânico empregado e suas concentrações, número de agitações e centrifugações realizadas para separação dos metabólitos hormonais presentes no material fecal.

Assim, enzimaimunoensaios para progestágenos já foram usados no monitoramento não invasivo da função endócrina durante o ciclo estral, gestação, e período pós-parto em veados (Mazama gouazoubira) (PEREIRA et al., 2006). Da mesma maneira, o trabalho desenvolvido por Songsasen et al. (2006), focado na avaliação da função gonadal da fêmea do Lobo guará (Chrysocyon brachyurus) teve resultados com sucesso e similares aos achados através do RIE. 


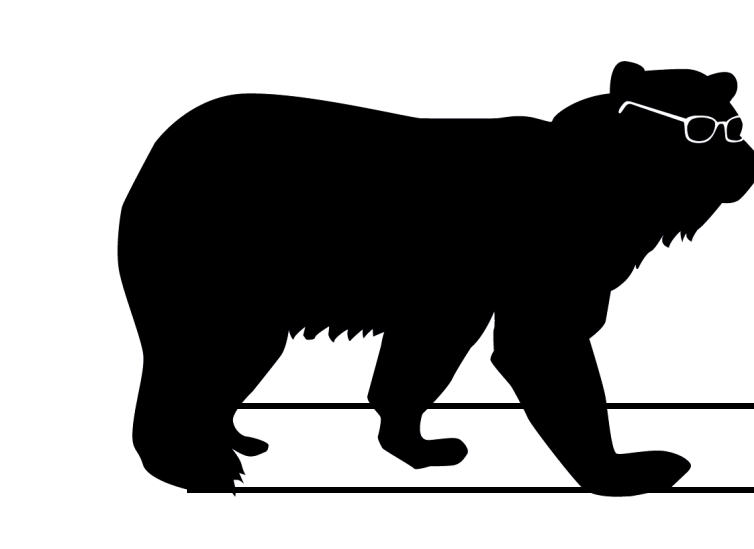




\section{OBJETIVOS}

\section{Geral}

- Caracterizar o perfil endócrino da atividade ovariana em fêmeas cativas de Ursode-óculos.

\section{Específicos}

- Testar um protocolo de indução de ovulação com o uso da aplicação exógena de um análogo do hormônio $\mathrm{GnRH}$.

- Investigar o padrão da atividade ovariana nas diferentes estações do ano, de acordo com as variações das concentrações de metabolitos fecais dos esteroides progesterona e estradiol. 



\section{MATERIAL E MÉTODO}

Neste estudo foram utilizadas amostras biológicas oriundas de duas instituições zoológicas da cidade de Lima-Peru. A colheita de amostras de fezes foi realizada entre os meses de Fevereiro de 2010 e Abril de 2011, e permitida pelo Governo Peruano através das autorizações: 1). Resolución Directoral n RD-4302009-AG-DGFFS-DGEFFS de Novembro de 2009 e 2). Resolución Directoral $n^{\circ}$ RD291-2011-AG-DGFFS-DGEFFS de Maio de 2011, ambas emitidas pela Dirección General Forestal y de Fauna Silvestre (DGFFS) do Ministério de Agricultura (MINAG) do Peru, instituição responsável pela regulação e emissão de autorizações de pesquisa e de importação/exportação de material biológico de fauna silvestre. As autorizações foram emitidas em nome do projeto "Caracterización del ciclo ovárico en la hembra de Oso de Anteojos (Tremarctos ornatus) mediante el uso de análisis hormonal no invasivo".

No Brasil, a pesquisa foi certificada através do protocolo $n^{0}$ 2225/2011, emitido o 27 de Junho de 2011, pela Comissão de Ética no uso de animais, da Faculdade de Medicina Veterinária e Zootecnia da Universidade de São Paulo.

\subsection{Animais e Instalações experimentais}

Foram estudadas seis (06) fêmeas adultas de Urso-de-óculos (Tremarctos ornatus) (Figura 4). Os animais se apresentavam clinicamente saudáveis, com um score de condição corporal em média de 3,5 sobre 5 , sendo mantidos em cativeiro 
em dois zoológicos da cidade de Lima-Peru, a saber: O Patronato del Parque de Las Leyendas "Felipe Benavides Barreda" (PATPAL), instituição pública, localizada no distrito de San Miguel, província de Lima, estado de Lima, a 7705’14.79” de longitude Oeste e $12^{\circ} 04^{\prime} 21.30^{\prime \prime}$ de latitude Sul, numa altitude de 59 m.s.n.m., e o Parque Zoológico Huachipa (PZH), instituição privada, localizada no distrito de AteVitarte, província de Lima, estado de Lima, a 7653'58.42" de longitude Oeste e $12^{\circ} 00^{\prime} 54.58^{\prime \prime}$ de latitude Sul, numa altitude de 382 m.s.n.m.

Do total de animais, quatro (04) fêmeas eram pertencentes ao PATPAL, e duas (02) pertencentes ao PZH. As idades dos animais foram estimadas baseandose numa provável data de nascimento antes de chegar à instituição, sendo que todas foram procedentes da natureza, confiscadas de caçadores, mercados negros ou circos das cidades do interior do Peru.

Na tabela 1 são apresentados os dados individuais dos animais, como identificação, instituição mantenedora e idades estimadas.

Tabela 1 - Identificação e idade estimada das fêmeas utilizadas no estudo

\begin{tabular}{c|c|c|c}
\hline Nome & Instituição & $\begin{array}{c}\text { Data de nascimento } \\
\text { estimada }\end{array}$ & $\begin{array}{c}\text { Idade estimada ao } \\
\text { inicio do estudo }\end{array}$ \\
\hline Candy & PATPAL & Janeiro 1993 & 17 anos 01 mês \\
Luna & PATPAL & Janeiro 1999 & 11 anos 01 mês \\
Susy & PATPAL & Maio 1994 & 15 anos 08 meses \\
Estrella & PATPAL & Janeiro 1999 & 11 anos 01 mês \\
Hana & PZH & Agosto 1998 & 11 anos 07 meses \\
Petsi & PZH & Ano 1993 & 17 anos. \\
\hline
\end{tabular}


Figura 4 - As fêmeas utilizadas no estudo. A. Candy, B. Susy, C. Luna, D. Estrella, E. Hana, F. Petsi

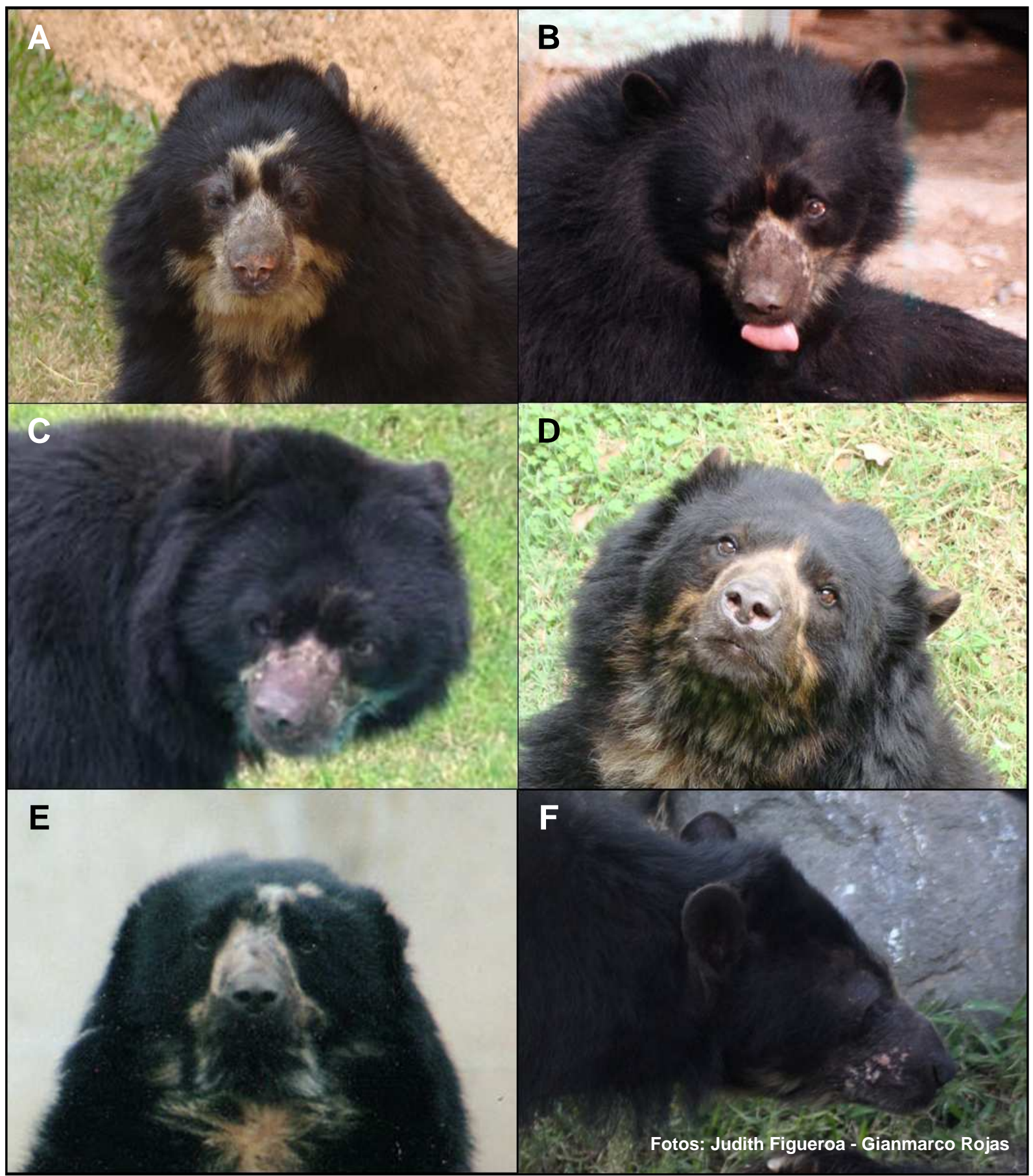


As fêmeas ficaram alojadas em recintos de exibição (Figura 5) com um ou vários machos. No PATPAL, a Candy encontrava-se no Setor Internacional, com uma área de exibição de $\sim 200 \mathrm{~m}^{2}$ e o cambiamento de $\sim 20 \mathrm{~m}^{2}$. A fêmea era mantida o tempo todo com o macho. No caso da Susy, Luna e Estrella elas encontravam-se na Zona Selva, num recinto de $\sim 265 \mathrm{~m}^{2}$ na exibição e de $\sim 40 \mathrm{~m}^{2}$ no cambiamento. Elas alternavam a exibição diária e eram mantidas com machos durante o dia. No caso das duas fêmeas do PZH, elas também compartilhavam os seus recintos de exibição com machos, mas nos cambiamentos foram separados. As dimensões dos recintos de exibição foram de $\sim 300 \mathrm{~m}^{2}$ cada, e dos cambiamentos, de $\sim 30 \mathrm{~m}^{2}$ cada. Do histórico reprodutivo dos animais pode-se destacar que nenhuma das fêmeas nos dois zoológicos se reproduziram no cativeiro.

\subsection{Validação fisiológica/Indução de ovulação}

Para realizar a validação fisiológica no estudo, foram utilizadas as duas fêmeas do $\mathrm{PZH}$, com as quais se realizou o desafio da aplicação de um análogo de $\mathrm{GnRH}$ para induzir um ciclo ovulatório e mensurar as variações nas concentrações dos metabólitos fecais de estradiol e/ou progesterona. Foi aplicada uma dose arbitraria única de Acetato de Gonadorelina (Lecirelina) (Gestran Plus ${ }^{\circledR}$, Tecnopec, São Paulo, Brasil) de 50 g via IM em um dardo, por meio de uma zarabatana (Figura 6). O protocolo de amostragem para este caso foi de coleta contínua por seis dias consecutivos antes do dia da aplicação, e oito dias consecutivos após aplicação. 
Figura 5 - Recintos de exibição das fêmeas de Urso-de-óculos. A. Parque Zoológico Huachipa, B. Patronato Parque de Las Leyendas "Felipe Benavides Barreda"

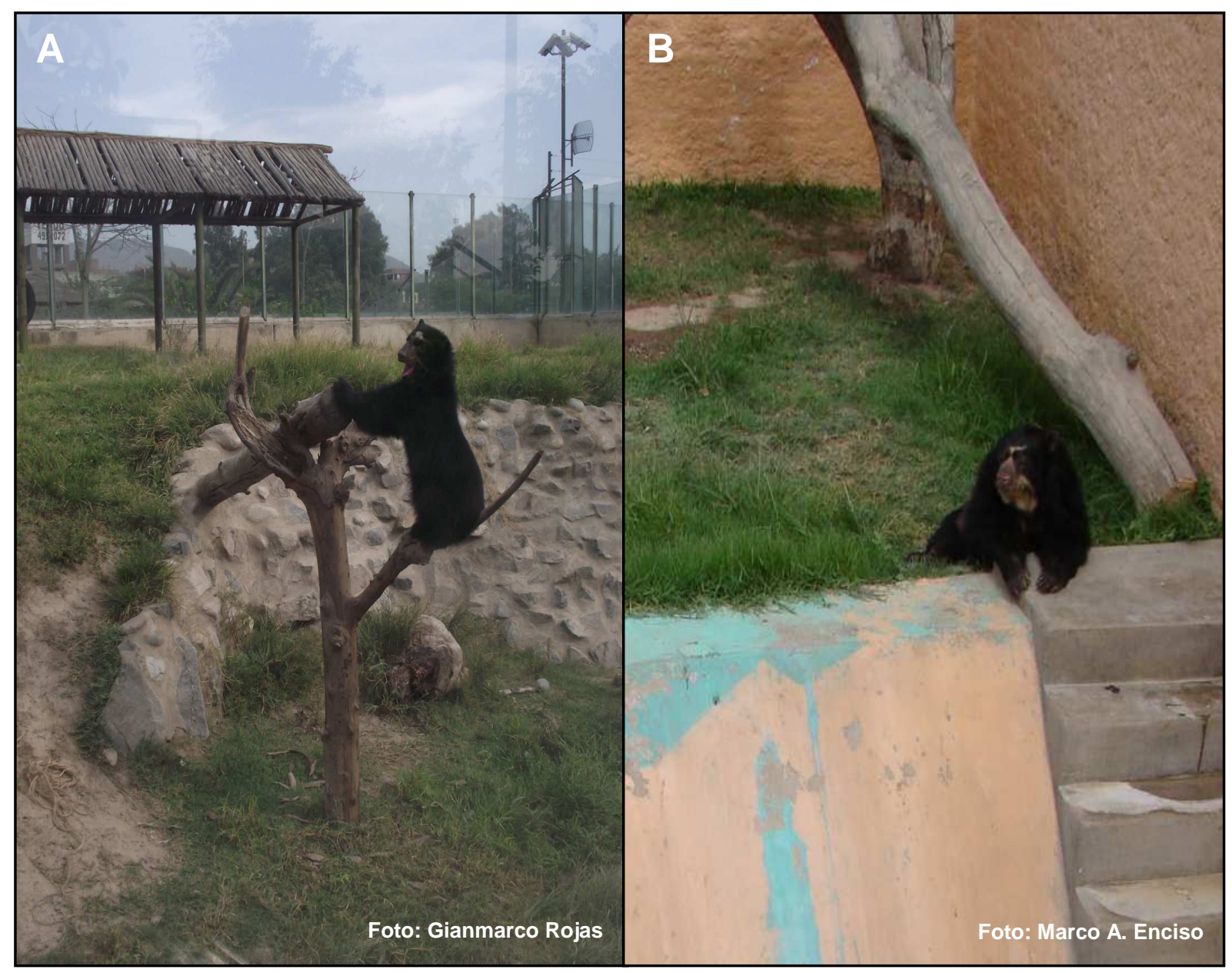


Figura 6 - Aplicação do hormônio para a validação fisiológica/indução de ovulação. A. O produto aplicado, Gestran Plus ${ }^{\circledR}$ (Tecnopec, São Paulo, Brasil). B. Lançamento do dardo mediante zarabatana

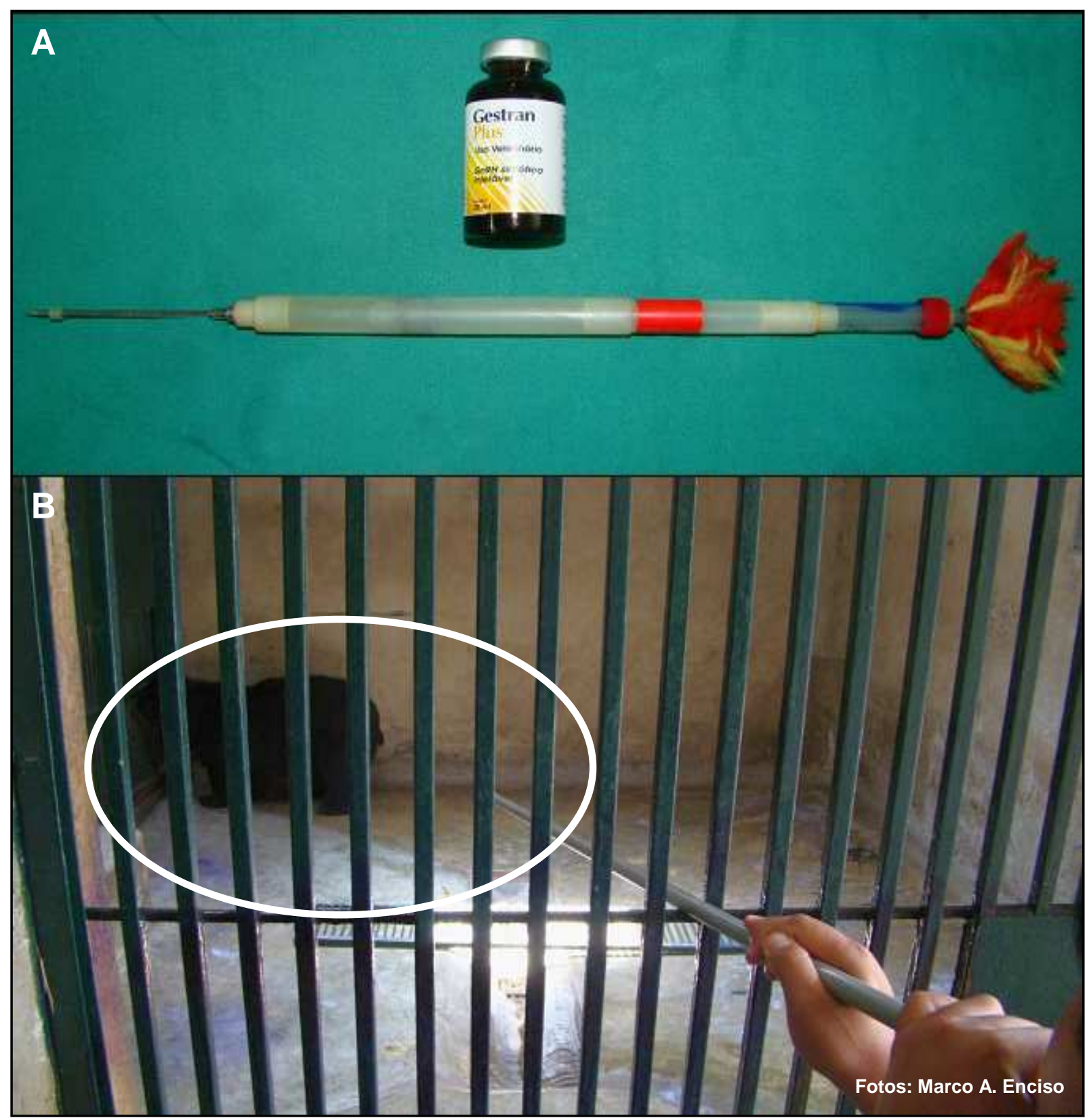




\subsection{Validação biológica}

A validação biológica foi feita pela observação das repetições das variações cíclicas das concentrações de metabólitos durante os treze meses do experimento.

\subsection{Colheita e armazenamento das amostras}

A amostragem foi iniciada em Fevereiro de 2010 no PATPAL e Março de 2010 no PZH, e teve uma duração de treze meses em cada um. As amostras fecais foram colhidas nas primeiras horas da manhã de duas a três vezes por semana pelos tratadores dos respectivos zoológicos, os quais foram treinados no correto procedimento de colheita.

Depois de colhidas foram acondicionadas em sacos plásticos do tipo "ziplock", identificadas e congeladas em freezer a uma temperatura de $-20^{\circ} \mathrm{C}$ em um prazo máximo de até 12 horas após a colheita, pois segundo Cockrem e Rounce (1994), a partir de pesquisas feitas com hormônios fecais em diversas espécies, se tem a estimativa que dentro desse período de tempo há um menor risco de se ter uma degradação hormonal significativa. As amostras foram mantidas no freezer até o descongelamento para realização do processo de extração dos metabólitos no laboratório. O numero total de amostras é detalhado na tabela 2. 
Tabela 2 - Total de amostras de fezes colhidas durante o período de amostragem

\begin{tabular}{c|c|c}
\hline Nome & Instituição & Número total de amostras \\
\hline Candy & PATPAL & 154 \\
Luna & PATPAL & 131 \\
Susy & PATPAL & 107 \\
Estrella & PATPAL & 130 \\
Hana & PZH & $155^{*}$ \\
Petsi & PZH & $174^{*}$ \\
\hline \multicolumn{2}{r|}{} \\
\hline
\end{tabular}

Legenda: *incluem as 14 amostras da validação

\subsection{Processamento das amostras: extração}

A etapa de extração foi realizada na "Sección de Biotecnología Reproductiva" do Laboratório de Reprodução Animal da Facultad de Medicina Veterinaria, Universidad Nacional Mayor de San Marcos, na cidade de Lima-Peru. A metodologia empregada na extração dos metabólitos fecais foi de acordo com a técnica descrita e padronizada por Möstl e Palme (2009).

Alíquotas de $0,5 \mathrm{~g}$ de fezes descongeladas foram pesadas em uma balança analítica (Sartorius ${ }^{\circledR}$ modelo TE214S, Göttingen, Alemanha), colocadas em tubos de $15 \mathrm{ml}$ e adicionados $5 \mathrm{ml}$ de etanol (Etanol, P.A. - Merck $^{\circledR}$ ) a $80 \%$ (80 \% etanol: 20 $\%$ água destilada). Os tubos foram fechados e agitados suavemente em aparelho homogeneizador (Vortex IKA ${ }^{\circledR}$ modelo MS2 - Minishaker, Cologne, Alemanha) por 
15 minutos. Em seguida, as amostras foram centrifugadas a 2500 g por 15 minutos (Centrífuga Gemmy ${ }^{\circledR}$ modelo PLC-025, Taipei, Taiwan) e do sobrenadante resultante foram transferidos $1 \mathrm{ml}$ por duplicata para tubos de polipropileno de 1,8 $\mathrm{ml}$. Depois de finalizada a transferência do sobrenadante, os tubos foram encaminhados ao fluxo laminar com extrator de ar para acelerar a evaporação do etanol. Os tubos secos foram fechados num ambiente estéril, devidamente identificados, e estocados até as dosagens hormonais.

4.6 Dosagens e análises hormonais por Enzimaimonoensaio (EIE)

Os metabólitos fecais foram quantificados por enzimaimunoensaio (EIE) de acordo com os procedimentos descritos para mamíferos (PALME; MÖSTL, 1997; MÖSTL; RETTENBACHER; PALME, 2005; PALME, 2005; PALME et al., 2005; TOUMA; PALME, 2005; HEISTERMANN; PALME; GANSWINDT, 2006). As dosagens foram realizadas no Instituto de Bioquímica Médica, Veterinärmedizinische Universität Wien-Áustria.

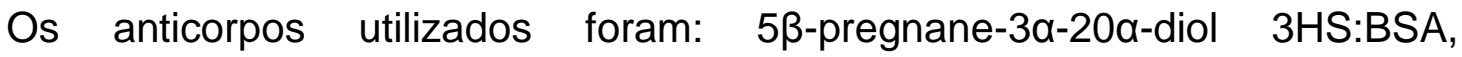
comumente conhecido como Pregnanediol, e 5a-androstane-3,17-dione 3CMO:BSA, chamado comumente com Epi-androsterona. Foram utilizadas microplacas de polietireno de 96 poços de alta absorção (MaxiSorp ${ }^{\circledR}$, Nunc Co., Rochester, NY, EUA), as quais foram seladas com um adesivo de acetato.

As microplacas foram marcadas (50 $\mu \mathrm{l} / \mathrm{poço})$ com anticorpo diluído em solução de marcação $\left(\mathrm{Na}_{2} \mathrm{CO}_{3}: 1,59 \mathrm{~g} / \mathrm{l} ; \mathrm{NaHCO}_{3}: 2,93 \mathrm{~g} / \mathrm{l} ; \mathrm{pH}: 9,6\right)$ e incubadas a 4 
${ }^{\circ} \mathrm{C}$ por 16 h. Após a incubação, as placas foram submetidas a um ciclo de três lavagens com solução de lavagem ( $\mathrm{NaCl}: 87,66$ g/l; Tween-20: 0,5 \%).

Em seguida, $150 \mu \mathrm{l}$ de cada extrato fecal foram colocados em tubos de vidro de $15 \mathrm{ml}$ e deixados em temperatura ambiente para evaporação. Após a secagem, o material foi ressuspendido com uma solução de hormônio conjugado com uma enzima peroxidase diluída em solução tampão $\left(\mathrm{NaH}_{2} \mathrm{PO}_{4} \mathrm{H}_{2} \mathrm{O}: 5,421 \mathrm{~g} / \mathrm{l} ; \mathrm{Na}_{2} \mathrm{HPO}_{4}\right.$ : 8,662 g/l; NaCl: 8,7 g/l; BSA: 1,0 g/l; ph: 7,0).

Foram adicionados $50 \mu \mathrm{l}$ de solução tampão em cada poço e posteriormente $50 \mu \mathrm{l}$ de cada padrão da curva $(0,1-10.000 \mathrm{pg} / \mathrm{ml})$ dos controles ou da solução de amostra com peroxidase. As microplacas foram seladas e incubadas por duas horas em temperatura ambiente.

Após incubação, as microplacas foram lavadas, secas e posteriormente foi adicionado $100 \mu \mathrm{l} /$ poço de substrato cromógeno. A reação cromógena foi parada com $100 \mu \mathrm{l}$ de solução Stop $\left(\mathrm{H}_{2} \mathrm{SO}_{4} 96\right.$ \%: $\left.10 \%\right)$. A densidade óptica foi medida com uma leitora automática (EL 808 Absorbance Microplate Reader ${ }^{\circledR}$, Biotek, Vermont, EUA), em conexão com um computador equipado com um software especial para cálculo. Foi utilizado um filtro de $450 \mathrm{~nm}$. Todas as amostras, controles e padrões foram analisados em duplicata.

Todos os parâmetros de controle de qualidade dos ensaios hormonais foram analisados conforme protocolo, ou seja, foram obtidos os coeficientes de variação inter e intra-ensaios, e as sensibilidades médias dos ensaios de pregnanediol e epiandrosterona. 


\subsubsection{Transformação das concentrações determinadas por EIE}

As concentrações determinadas por EIE foram expressas para os metabólitos em pg/poço, sendo necessária a adequação dos resultados para ng/g de fezes. Para essa adequação foi utilizada a seguinte equação (MÖSTL; PALME, 2010):

\footnotetext{
C X Vfe $\times$ D

$\mathrm{CF}=$

Pi x V x 1000
}

Onde:

CF: Concentração final, em ng (de esteroide) por $g$ (fezes);

C: Concentraçao fornecida pelo EIE, por poço;

Vfe: Volume das fezes na etapa da extração, em $\mathrm{mg}$ mais o solvente empregado, em $\mu l$;

D: Diluição empregada;

Pi: Peso inicial, expressado em g;

V: Volume transferido ao EIE, em $\mu$;

1000: Para dispor dos resultados expressados em $n g$, em vez de $p g$

\subsection{Validação laboratorial}

Foi realizada a validação laboratorial do EIE para o uso em extrato de fezes de Urso-de-óculos, utilizando o método de paralelismo entre a curva padrão e a curva diluída em matriz integra isenta de esteroides. Indica se o material utilizado 
está interferindo na ligação antígeno-anticorpo. Foi utilizado um "pool" de amostras de alta concentração hormonal (valores próximos aos limites superiores da curvapadrão). Estas amostras foram diluídas com o mesmo fator da curva padrão.

\subsection{Análise estatística}

Para a análise de características do ciclo ovariano foram utilizados os resultados das mensurações dos metabolitos fecais de estradiol e progesterona. Os valores de linha de base foram determinados por um processo iterativo em que os valores elevados que ultrapassem a média acrescida de um e meio desvios-padrão foram selecionados como surgimento de picos deste hormônio (BROWN et al., 1994; MOREIRA et al., 2001; STOOPS; MACKINNON; ROTH, 2012). Desta maneira os valores de pico foram considerados significativos se estes excederam o critério anteriormente citado.

Todos os resultados descritos foram expressos de acordo com suas médias e erro padrão das médias. As variáveis foram primeiramente analisadas quanto à sua distribuição pelo teste de Kolmogorov-Smirnov para verificação da normalidade e o teste do Bartlett para homogeneidade das variâncias. Caso, os dados não obedecessem estas premissas eram transformados mediante o logaritmo na base 10 $-\log _{10} X$ ou raiz quadrada de $X-\sqrt{ } X$.

Para os resultados comparativos das análises mensais e sazonais foi utilizado o teste de Análise de variância one way ANOVA e o teste de comparação entre médias de Tukey $(p<0,05)$ dos dados transformados $\left(\log _{10} X\right)$. Caso os dados 
transformados não obedecessem a uma distribuição normal, foi utilizado o teste não paramétrico de Kruskall Wallis, seguido do pós-teste de Dunn $(p<0,05)$.

As análises estatísticas e gráficos de resultados foram realizados com 0 auxilio do programa GraphPad Prism ${ }^{\circledR}$ versão 5.04 para Windows ${ }^{\circledR}$. (GraphPad Software, San Diego, CA, EUA). 
$m$ 


\section{$5 \quad$ RESULTADOS E DISCUSSÃO}

Os resultados e discussão serão apresentados conjuntamente para melhor compreensão. Os resultados da validação fisiológica assim como o da análise longitudinal dos metabólitos fecais ao longo do ano serão apresentados em seções específicas.

\subsection{Validação fisiológica}

Os resultados do desafio hormonal com o análogo de $\mathrm{GnRH}$ serão apresentados para cada fêmea estudada. Considerando que se trabalhou com duas fêmeas, e, para cada desafio foram coletadas 14 amostras de fezes, o numero total de amostras dosadas para estradiol e progesterona foi de 28.

Os gráficos 1 e 2 apresentam as concentrações do metabólito fecal de progesterona (MFP), e do metabólito fecal de estradiol (MFE); nas fêmeas Hana e Petsi respectivamente, submetidas ao desafio com o Acetato de Gonadorelina. 
Gráfico 1 - Concentrações dos metabólitos fecais de estradiol (E-A) e progesterona (PDG) na fêmea Hana no desafio de análogo de $\mathrm{GnRH}$ para validação fisiológica

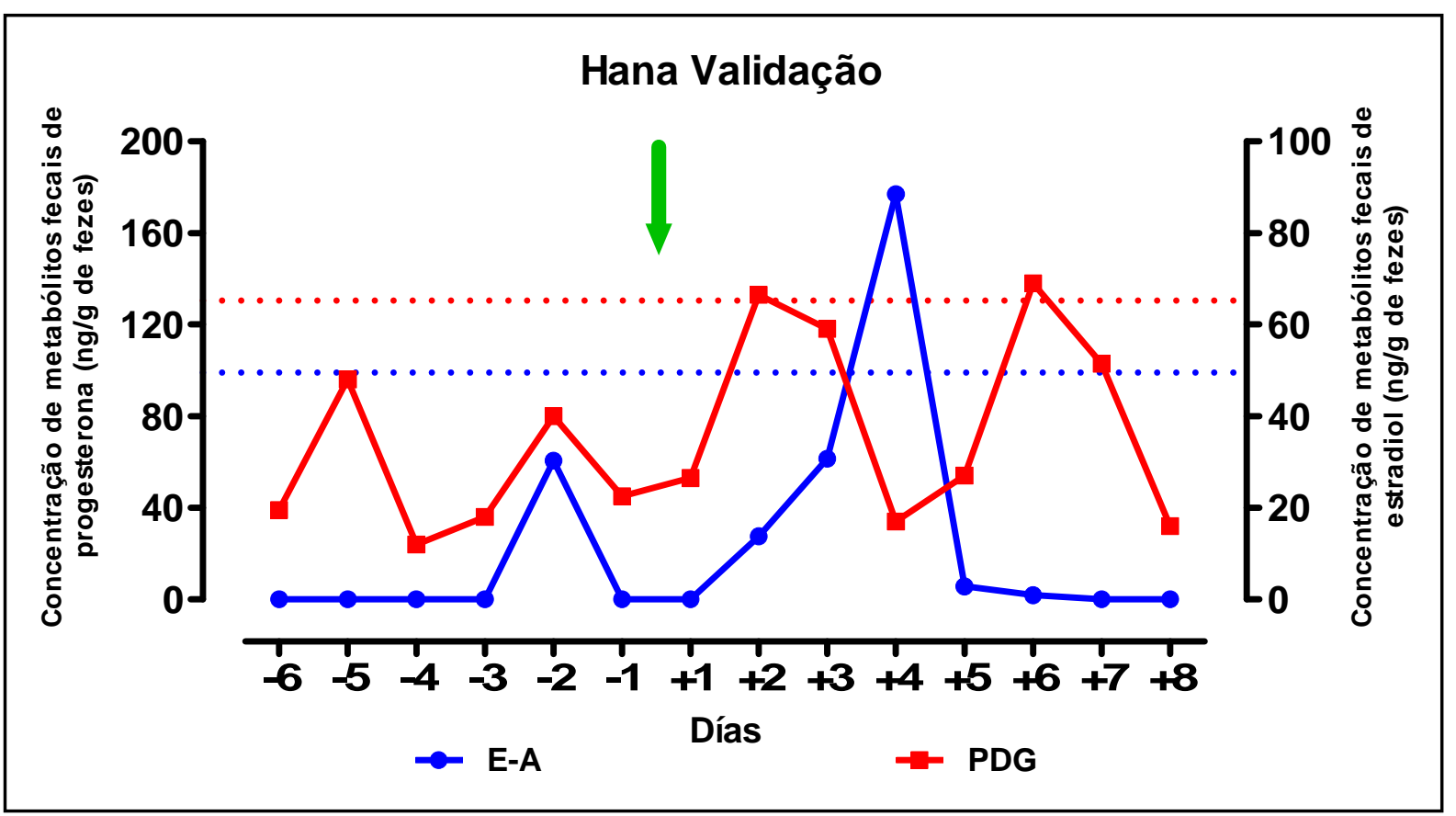

LEGENDA: A seta verde representa o dia de aplicação do análogo de GnRH. As linhas pontuadas de cor vermelho e azul representa o limiar estabelecido para os picos de cada hormônio

Gráfico 2 - Concentrações dos metabólitos fecais de estradiol (E-A) e progesterona (PDG) na fêmea Petsi no desafio de análogo de GnRH para validação fisiológica

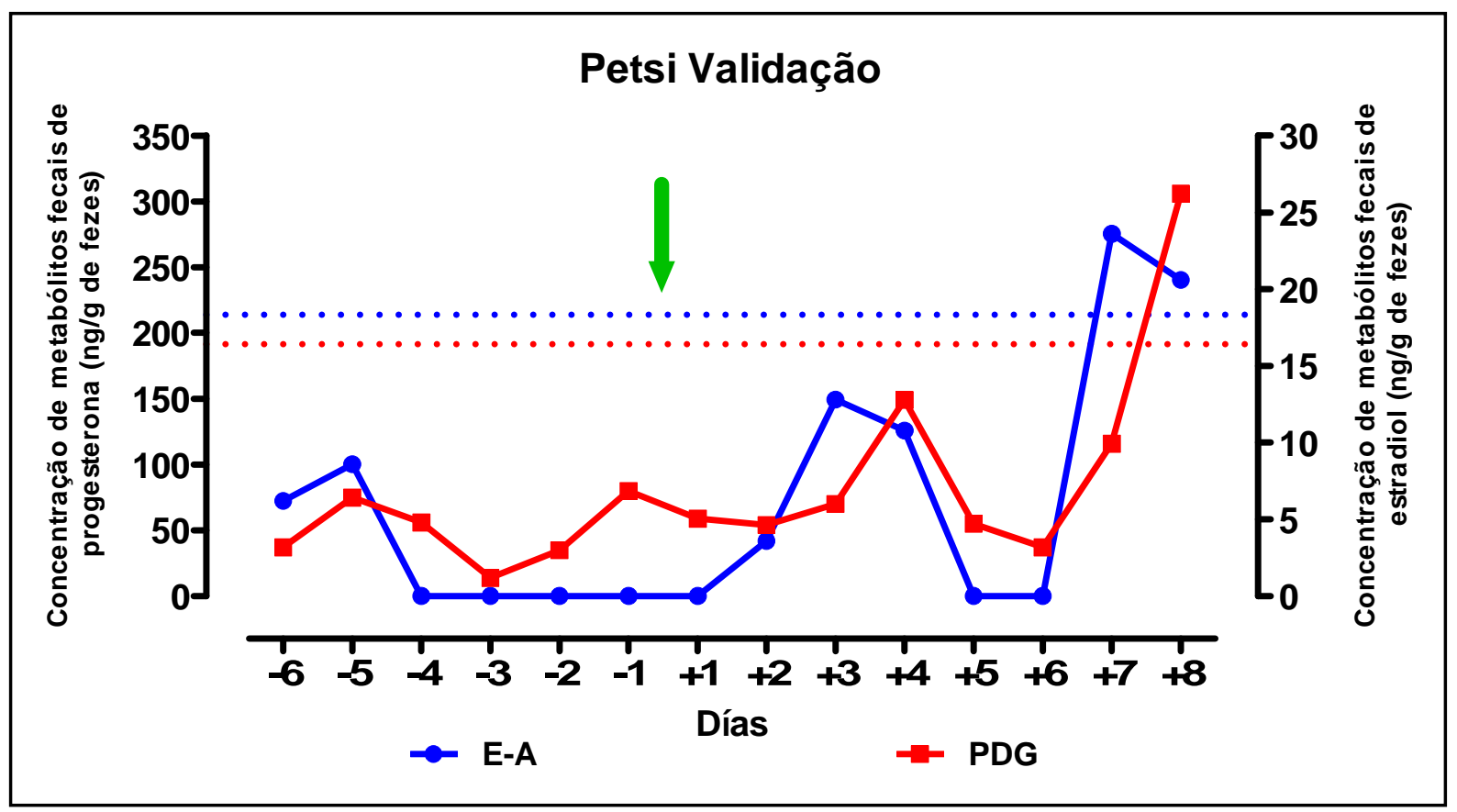

LEGENDA: A seta verde representa o dia de aplicação do análogo de $\mathrm{GnRH}$. As linhas pontuadas de cor vermelho e azul representa o limiar estabelecido para os picos de cada hormônio 
Analisando os gráficos apresentados individualmente, no caso da Hana, verificou-se que após da aplicação do Acetato de Gonadorelina, ocorreu um aumento gradativo das concentrações dos MFP e MFE, sendo que para a progesterona, ocorre a partir das $24 \mathrm{~h}$ após aplicação, atingindo o pico às $48 \mathrm{~h}$, e é observada a sua queda a partir das 72 h. No caso do estradiol o aumento é gradativo e notável, ocorrendo o incremento das concentrações desde o segundo dia após aplicação e atingindo um pico ao quarto dia, e uma queda marcada já no quinto dia. Então, na Hana pode-se verificar uma atividade ovariana como resposta à estimulação com o análogo da $\mathrm{GnRH}$, e pode-se inferir que houve um crescimento folicular, mas sem comprovar-se uma ovulação.

No caso da Petsi, os resultados não foram satisfatórios, devido a que não foi observado nenhum pico hormonal após aplicação do análogo de $\mathrm{GnRH}$. Ocorrem aumentos nas concentrações dos MFE e MFP nos dias 3 e 4 respectivamente, mas não atingem o limiar estabelecido para ser considerados picos após estímulo. Nos dias 7 e 8 pode-se observar um aumento nos dois hormônios, mas isto poderia se dever a uma atividade ovariana natural sem relação com a aplicação do Acetato de Gonadorelina. Os resultados obtidos sugerem que Petsi não apresentou resposta ao estímulo. Este resultado pode ser devido a fatores intrínsecos do individuo ou estar relacionado à dose de análogo de $\mathrm{GnRH}$ aplicada, porque que esta foi designada arbitrariamente, já que não se dispõe de doses estabelecidas para à espécie.

Os hormônios esteroides são rapidamente eliminados do sangue. Eles são principalmente metabolizados pelo fígado e excretados na urina e bílis como conjugados. No intestino maioria deles são desconjugados por bactérias e parcialmente reabsorvidos. Um exemplo disso é a circulação entero-hepática de esteroides, descrita em ovinos e suínos. Os esteroides, que não são reabsorvidos, 
são eliminados através das fezes; além disso, bactérias intestinais específicas também podem metabolizar os esteroides (WASSER et al., 1994; PALME et al., 1996). Por tal motivo é importante destacar que os diferentes hormônios são metabolizados em diferentes velocidades, então os perfis de metabólitos fecais podem apresentar uma relação de aparição temporal diferente do sangue, o que poderia explicar porque o pico de MFE aconteceu simultaneamente ou logo depois ao pico do MFP, como se pode observar no perfil da Hana.

Da mesma maneira, se deve ressaltar a importância da velocidade do trânsito intestinal (desde o duodeno para o reto) para a excreção dos esteroides nas fezes. O tempo necessário para que um aumento de concentração sérica seja refletido nas concentrações de metabólicos fecais vai variar entre as espécies.

Por exemplo, nos animais domésticos, os ovinos tem uma aparição muito rápida de picos de esteroides nas fezes, ao redor de 9 horas; já nos equinos pode ser desde as 12 horas e nos suínos, pode estar em torno de 1 a 2 dias (PALME et al., 1996). Porém, como não se dispõe de dados da velocidade do trânsito intestinal no Urso-de-óculos, se faz uma aproximação do tempo de excreção dos metabólitos de 48 horas no máximo; semelhante ao suíno, que tem uma dieta onívoro-herbívora. No cativeiro, a dieta do Urso-de-óculos está baseada em vegetais, algumas frutas e proteína de origem animal. A dieta dos animais mantidos nos zoológicos aparece no anexo $\mathrm{A}$. 
5.2 Análise longitudinal

Os resultados da análise longitudinal durante os 13 meses de amostragem será apresentado para cada fêmea individualmente, sendo que os gráficos serão agrupados de acordo com a procedência dos animais: PZH e PATPAL. No gráfico 3 se apresentam os resultados das concentrações de metabólitos hormonais das duas fêmeas do $\mathrm{PZH}$.

Gráfico 3 - Perfis das concentrações de metabólitos fecais de estradiol (E-A) e progesterona (PDG) nas duas fêmeas do PZH, desde Março de 2010 a Março de 2011
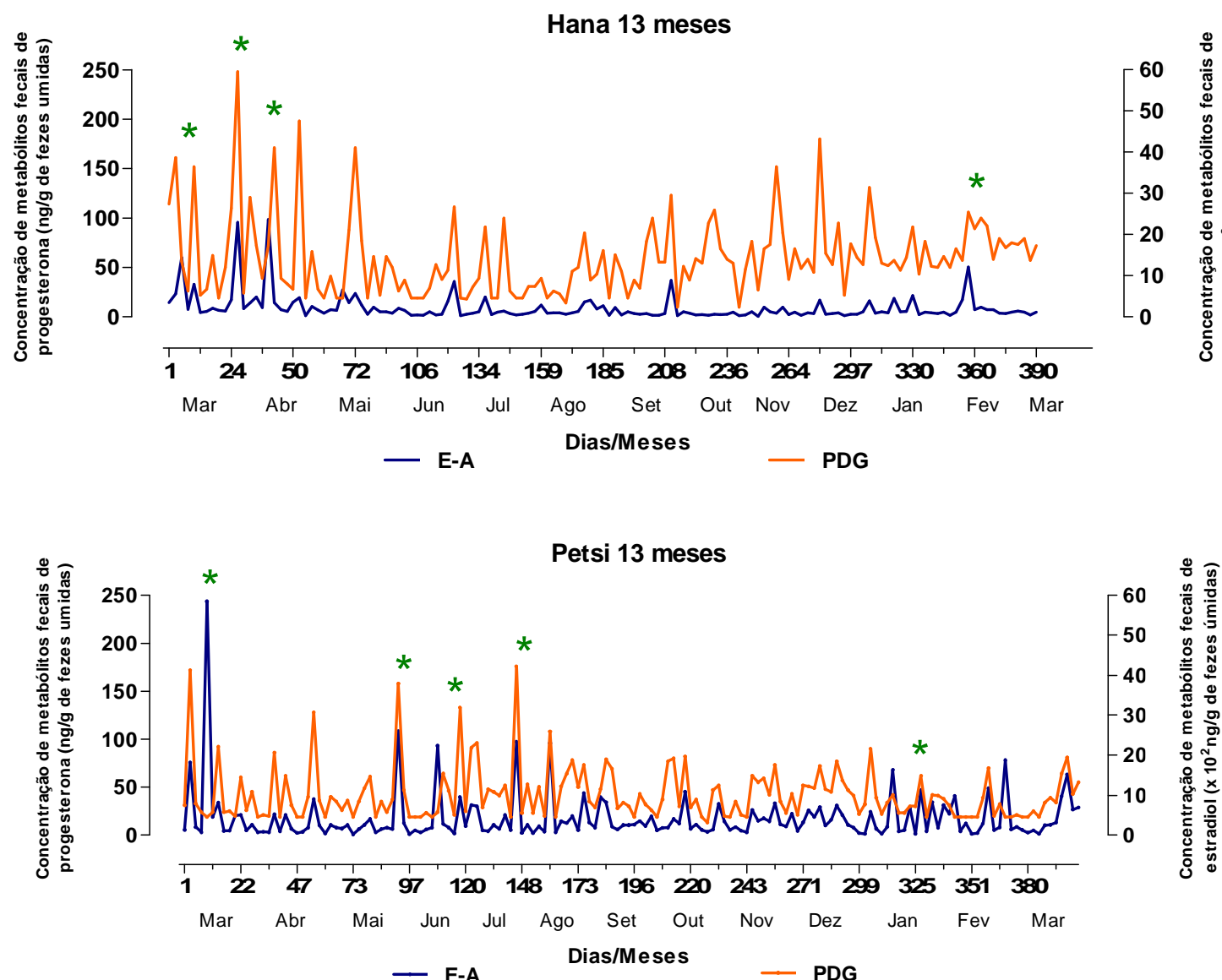

Legenda: Os asteriscos representam o período de atividade ovariana, representado pela ocorrência de concentrações de picos de MFE e MFP 
Analisando os perfis das concentrações hormonais durante os 13 meses, a Hana apresentou pelo menos quatro eventos que podem sugerir períodos marcados de atividade ovariana e possível ocorrência de ovulação. Estes foram representados pelo agrupamento dos aumentos concomitantes das concentrações dos MFE e MFP, os quais ultrapassaram os valores calculados para ser considerados como pico; $717,1 \mathrm{ng} / \mathrm{g}$ para MFE (E-A) e 121,1 ng/g para MFP (PDG). Além disso, se podem observar variações das concentrações do MFE e MFP durante estes períodos, o que evidencia uma atividade ovariana em diferentes épocas do ano. Pode-se observar também que estes períodos de atividade ocorreram entre Março e Abril de 2010, com outro período ainda em finais de Fevereiro de 2011. Isto é compatível com a atividade reprodutiva reportada para a espécie, tanto na vida livre como em cativeiro de Fev/Mar até Set/Out (PEYTON, 1999; BRACHO, 2002, SPADY; LINDBURG; DURRANT, 2007). Como a literatura descreve que a maioria dos ursos podem ser ovuladores induzidos (BOONE et al., 1998, 2004), os episódios de valores altos de MFP podem estar relacionados a possíveis situações de acasalamento com o macho com quem a Hana alternou o recinto de exibição, porém não há registros destes eventos.

No caso da Petsi, os perfis hormonais seguem o mesmo padrão observado na Hana, foram registrados cinco eventos que sugerem períodos marcados de atividade ovariana, pela observação dos aumentos das concentrações de MFE e MFP, $1.383,5 \mathrm{ng} / \mathrm{g}$ para MFE e 85,3 ng/g para MFP. Estes períodos ocorreram em Março de 2010, e entre Junho e Julho de 2010; e o retorno da atividade em Janeiro de 2011. A fêmea também se encontrava pareada com um macho adulto na exibição, e não se pode descartar a existência de atividade copulatória mesmo que não se 
tenha estes registros. No entanto, em comparação com a Hana, há uma maior variabilidade das concentrações de MFE ao longo dos 13 meses.

No gráfico 4 se apresentam os resultados das concentrações hormonais das quatro fêmeas do PATPAL. 
Gráfico 4 - Perfis das concentrações de metabólitos fecais de estradiol (E-A) e progesterona (PDG) nas quatro fêmeas do PATPAL, desde Fevereiro de 2010 a Fevereiro de 2011

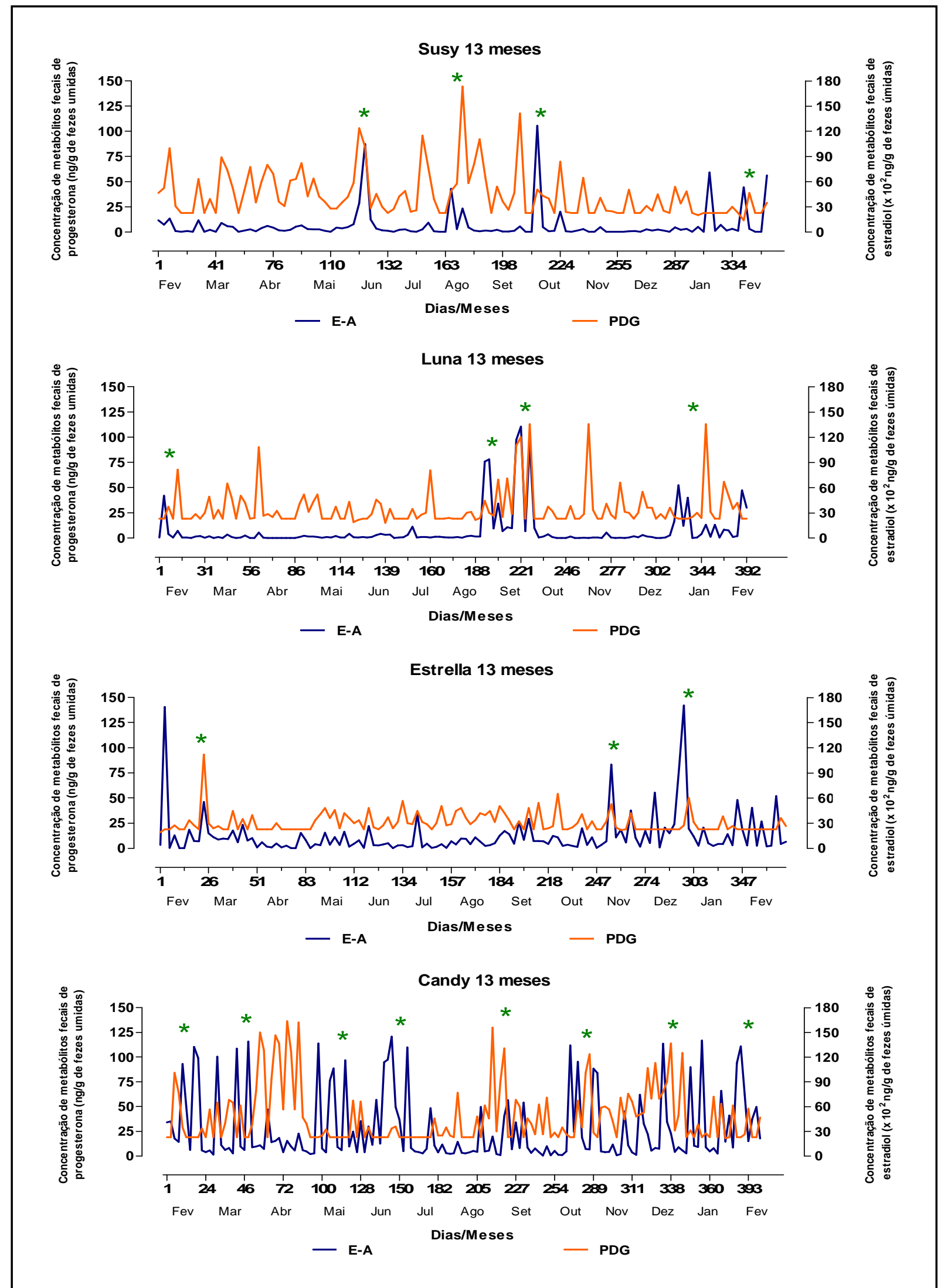

Legenda: Os asteriscos representam o período de atividade ovariana, representado pela ocorrência de concentrações de picos de MFE e MFP 
No gráfico, os resultados das concentrações dos metabólitos hormonais da Susy mostram quatro eventos que sugerem períodos marcados de atividade ovariana, representados pela ocorrência de aumentos concomitantes das concentrações dos MFE e MFP, ultrapassando os valores calculados para pico; $3.712,9 \mathrm{ng} / \mathrm{g}$ para MFE (E-A) e $72,3 \mathrm{ng} / \mathrm{g}$ para MFP (PDG). Estes eventos aconteceram entre começo de Junho, meados de Agosto, e começo de Outubro de 2010; e o retorno de atividade em Fevereiro de 2011. A Susy compartilhava o recinto de exibição com mais duas fêmeas, Luna e Estrella e mais dois machos; porém não há registros de atividade copulatória.

A Luna apresentou também quatro eventos que sugerem períodos de atividade ovariana, de acordo com os aumentos observados nas concentrações de MFE e MFP, superando os $4.337,2 \mathrm{ng} / \mathrm{g}$ para MFE e $58,7 \mathrm{ng} / \mathrm{g}$ para MFP. Os períodos de atividade ovariana foram observados, em Fevereiro e, entre Agosto e Setembro de 2010, e o seguinte em Janeiro de 2011. Os de Agosto e Setembro pode se considerar como tendo ocorridos dentro da época reprodutiva citada em literatura, mas o de Janeiro estaria adiantado a esta. Entre esses dois períodos não se notaram variações marcantes dos MFE, que apresentaram perfil de variações basais.

No caso da Estrella, ela apresentou pelo menos três eventos que podem sugerir períodos marcados de atividade ovariana. Os valores de concentrações mínimas consideradas para picos de MFE e MFP foram 5.385,0 ng/g e 40,4 ng/g respectivamente. Os períodos de atividade ovariana ocorreram em Fevereiro de 2010, e entre Novembro de 2010; e Janeiro de 2011. Foi observado um perfil de atividade de MFE, com concentrações de metabólitos acima dos valores basais, isso 
pode sugerir que a atividade ovariana esteja possivelmente relacionada à presença permanente dos machos no recinto.

Em relação à Candy, as variações das concentrações de metabólitos observados apresentam a particularidade de ter valores altos ao longo do ano todo, com até oito eventos que sugerem períodos marcados de atividade ovariana com uma duração de 07 dias em média, ultrapassando os valores calculados para pico; quais sejam 9550,5 ng/g para MFE (E-A) e 83,1 ng/g para MFP (PDG). Só se observou uma diminuição dos valores das concentrações para os MFE e MFP durante os meses de Julho e Agosto de 2010. Nos meses de Abril e Dezembro observou-se também um marcado aumento das concentrações do MFP sustentada no tempo por aproximadamente 24 e 20 dias respectivamente, o que poderia sugerir eventos de ovulação e manutenção de um corpo lúteo, ou até mesmo um início de prenhes que não foi mantida posteriormente. Por exemplo, num reporte de caso no Urso Pardo (Ursus arctos), se observou que os valores das concentrações fecais de progesterona se elevaram dramaticamente (acima dos $4600 \mathrm{ng} / \mathrm{g}$ ), durante uma implantação embrionária confirmada por ultrassonografía, sendo que foi observado um rápido declínio duas semanas depois, refletindo em uma interrupção da prenhes (DEHNHARD et al., 2006), isto poderia explicar os valores altos das concentrações do MFP e os eventos reprodutivos sugeridos anteriormente.

Da mesma maneira pode se sugerir o evento da pseudo-prenhes como responsável pelos picos dos MFP obtidos na Candy. Porém, podem ocorrer complicações quando se discute a fase lútea especialmente em espécies que apresentam pseudo-prenhes. A prenhes e a pseudo-prenhes aparecem como endocrinológicamente indistinguíveis nos ursos. Por exemplo, em ursas não prenhes, o perfil prolongado de progesterona pode ser tipicamente definido como 
pseudo-prenhes. Assim, é sugerido utilizar o termo "diestro" para se referir a uma fase lútea ativa (como no caso da pseudo-prenhes), e "anestro", para descrever períodos prolongados de inatividade reprodutiva (FREDERICK et al., 2010).

Ao contrario das outras três fêmeas do PATPAL, a Candy encontrava-se em outro recinto, menor, e com a presença permanente do macho, tanto em exibição quanto no cambiamento, sendo observadas copulas em múltiplas ocasiões. Estas ocorrências podem estar relacionadas à grande quantidade de picos de concentrações de metabólitos fecais de estrógenos e progestágenos observados. Este resultado sugere que o efeito macho pode ter-se refletido nos valores hormonais, e difere ao achado por Dehnhard et al. (2006) onde não foram observadas variações nos estrógenos na fêmea de Urso-de-óculos, mesmo quando era continuamente acasalada pelo macho.

Conforme os resultados obtidos para todas as fêmeas, pode-se observar a ocorrência de aparentemente três a quatro fases de atividade ovarianas por ano, a exceção da Candy que apresentou até oito fases de atividade ovariana e prováveis dois eventos compatíveis com ovulações. Na literatura, se reporta para o Urso-deóculos na vida livre, um tempo estimado de nove meses em média, como intervalo entre cada ciclo ovariano, com até uma ocorrência de máximos três ciclos consecutivos em 24 meses (SPADY; LINDBURG; DURRANT, 2007). Segundo o observado em nosso estudo, os resultados de todas fêmeas, de alguma maneira, foram compatíveis com esse perfil, com pequenas variações nas concentrações dos MFE e MFP que sugeriram atividade ovariana, mas sem a ocorrência de ovulação e/ou prenhes, apesar de todas estarem pareadas com machos a maior parte do tempo. 
No caso da Candy, são interessantes os dados obtidos, já que amostram uma aparente ovulação e manutenção do corpo lúteo. O fato de ter sido constantemente acasalada pelo macho explica certamente a ovulação, conforme ao relatado no Urso negro (Ursus americanus) que classifica a espécie como ovuladora induzida dependente da cópula, e que infere que em geral a família dos Ursídeos tem esta característica ou estratégia reprodutiva (BOONE et al., 2004). Porém, no caso de todas as outras fêmeas expostas aos machos, que não apresentaram evidencia de ovulação, mas apresentaram perfis de MFE sugestivos de atividade ovariana, se poderia sugerir que existe algum problema reprodutivo relativo aos machos, sendo que em nenhum dos zoológicos foi relatado algum nascimento ou gestação nas ursas. Além disso, a incompatibilidade entre fêmeas e machos poderia explicar este fenômeno.

A duração do estro está estreitamente associada à filogenia das espécies de ursos, sendo que, no caso do Urso-de-óculos, a estimativa da duração do estro é de 05 días (SPADY; LINDBURG; DURRANT, 2007). Segundo os nossos resultados, quando foi observado um período de atividade ovariana que pudesse ser associada ao estro, a duração destes foi entre três a oito dias. No entanto, sugere-se que dados devam ser complementados com observações comportamentais reprodutivas. Na mesma linha, a literatura manifesta que a variabilidade na duração do estro nos ursos pode estar relacionada à adaptação ao meio ambiente e à área de vida, com maior facilidade ou restrição na disponibilidade do alimento (POWELL; ZIMMERMAN; SEAMAN, 1997; FREDERICK et al., 2012). Fatores como os anteriormente citados estão presentes na natureza, mas não no cativeiro, onde o acesso ao alimento é geralmente regular e pode resultar em alterações no padrão do comportamento reprodutivo da espécie. 


\subsubsection{Análise mensal}

No gráfico 5 se apresentam os resultados das concentrações de metabólitos hormonais consolidadas por mês nas duas fêmeas do $\mathrm{PZH}$. Os resultados serão discutidos por animal.

Gráfico 5 - Concentrações médias e erros-padrão consolidados por mês dos metabólitos fecais de estradiol (E-A) e progesterona (PDG) nas fêmeas do PZH

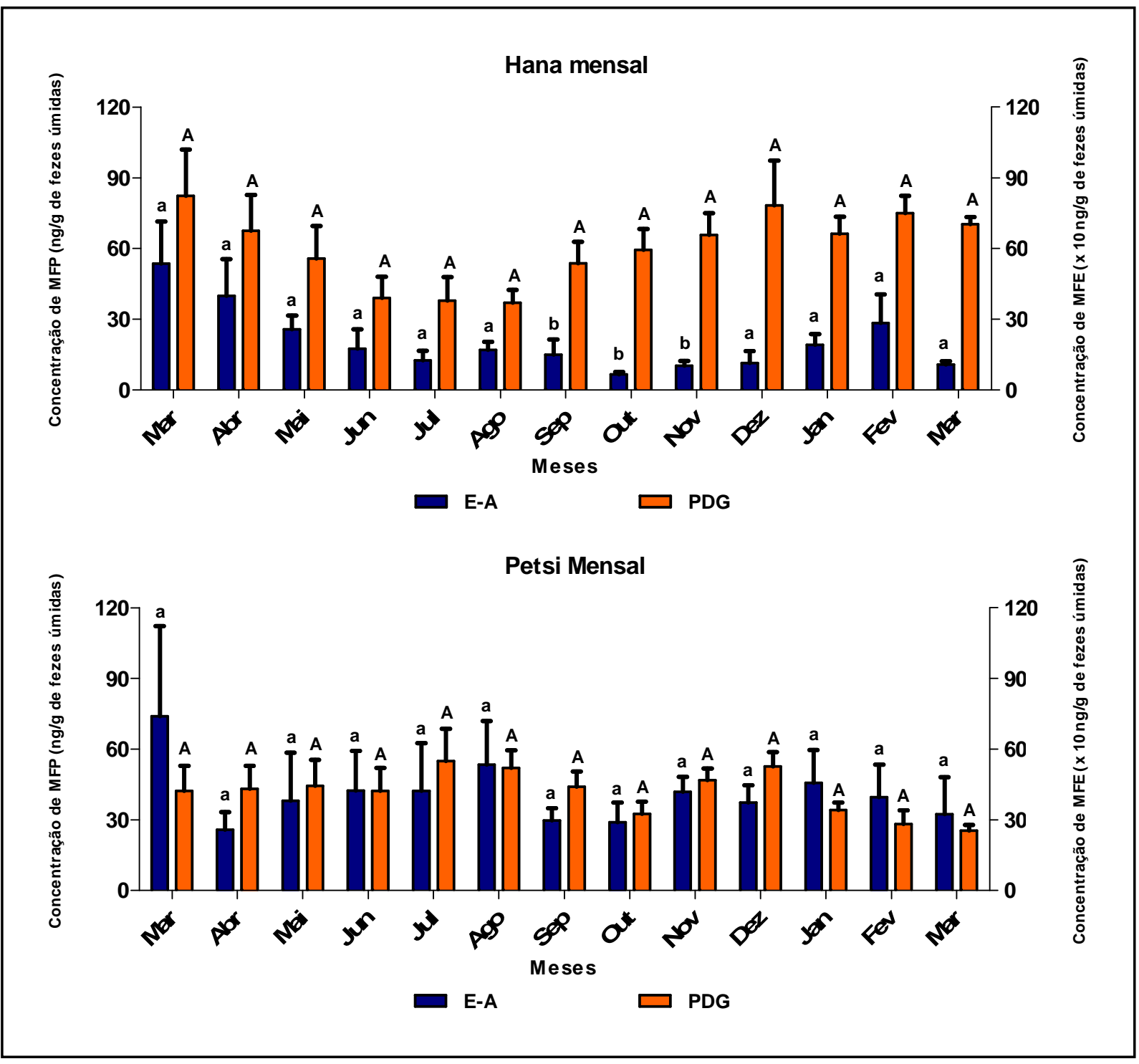

Legenda: Os dados são apresentados com Média \pm Erro padrão das médias, para cada metabólito. As letras diferentes representam diferencia estatística significativa entre meses 
Em relação às fêmeas do $\mathrm{PZH}$, para a Hana, segundo os resultados das comparações das médias das concentrações mensais de MFE, pode se observar uma diferença estatística significativa $(p<0,05)$ entre o mês de Março com os meses de Setembro, Outubro e Novembro, onde as médias dos valores das concentrações do MFE foram as mais baixas em comparação à Março. Já com o MFP não houve diferencia estatística ao longo do ano. No caso da Petsi, segundo o teste estatístico não houve diferencia significativa ao longo do ano para as médias mensais dos MFE e MFP.

Analisando os resultados obtidos nas médias por mês, pode se observar que a Hana teve um período de inatividade ovariana entre os meses de Setembro a Novembro; sendo que esse perfil coincide com a literatura que relata que a faixa de inatividade reprodutiva na natureza pode começar em Setembro até Dezembro ou Janeiro (PEYTON, 1999; SPADY; LINDBURG; DURRANT, 2007).

Nos gráficos 6 e 7 se apresentam os resultados das concentrações de metabólitos hormonais consolidadas por mês nas fêmeas do PATPAL. Os resultados serão discutidos individualmente. 
Gráfico 6 - Concentrações médias e erros-padrão consolidados por mês dos metabólitos fecais de estradiol (E-A) e progesterona (PDG) nas fêmeas Susy e Luna do PATPAL

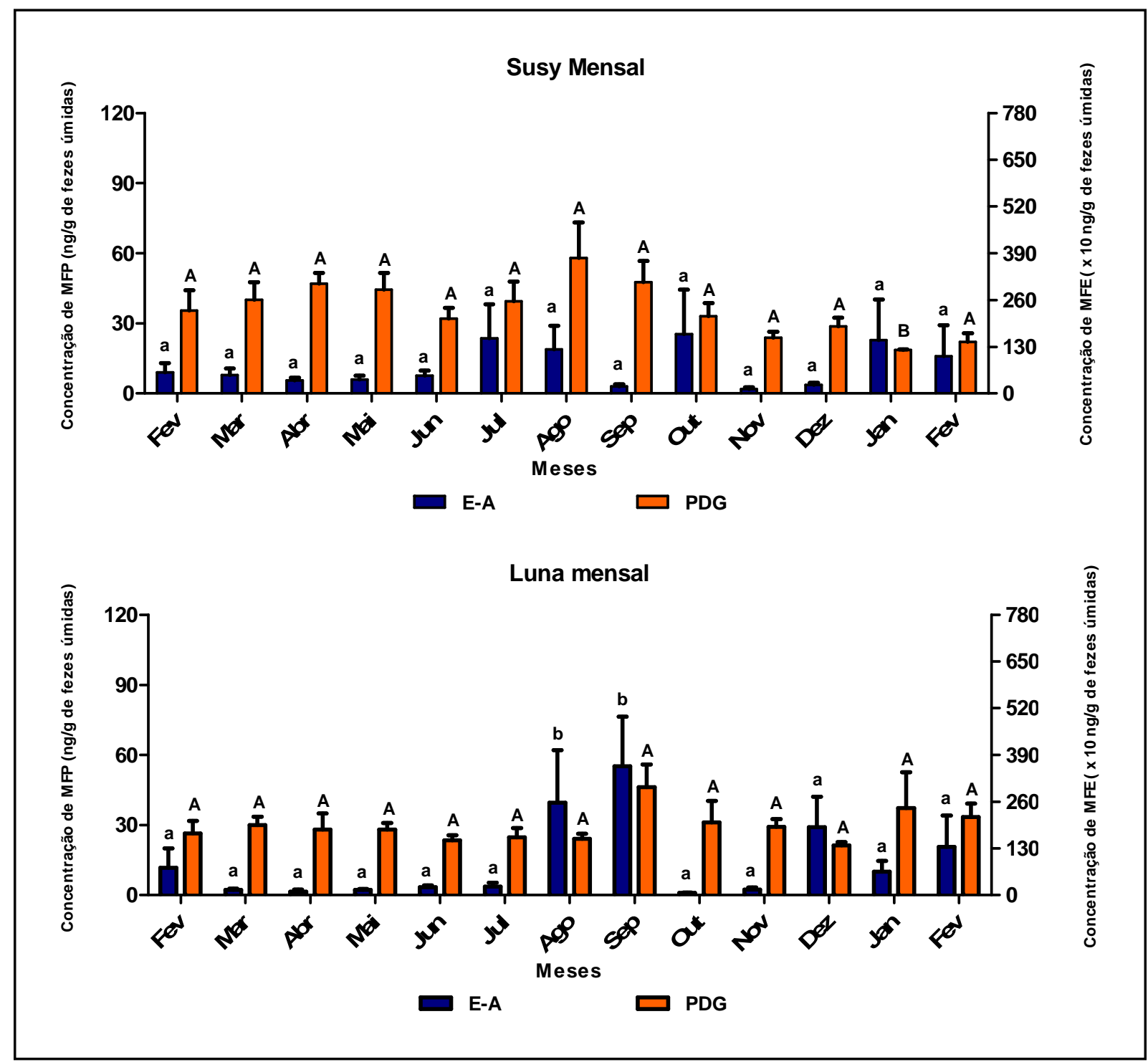

Legenda: Os dados são apresentados com Média \pm Erro padrão das médias, para cada metabólito. As letras diferentes representam diferencia estatística significativa entre meses 
Gráfico 7 - Concentrações médias e erros-padrão consolidados por mês dos metabólitos fecais de estradiol (E-A) e progesterona (PDG) nas fêmeas Estrella e Candy do PATPAL

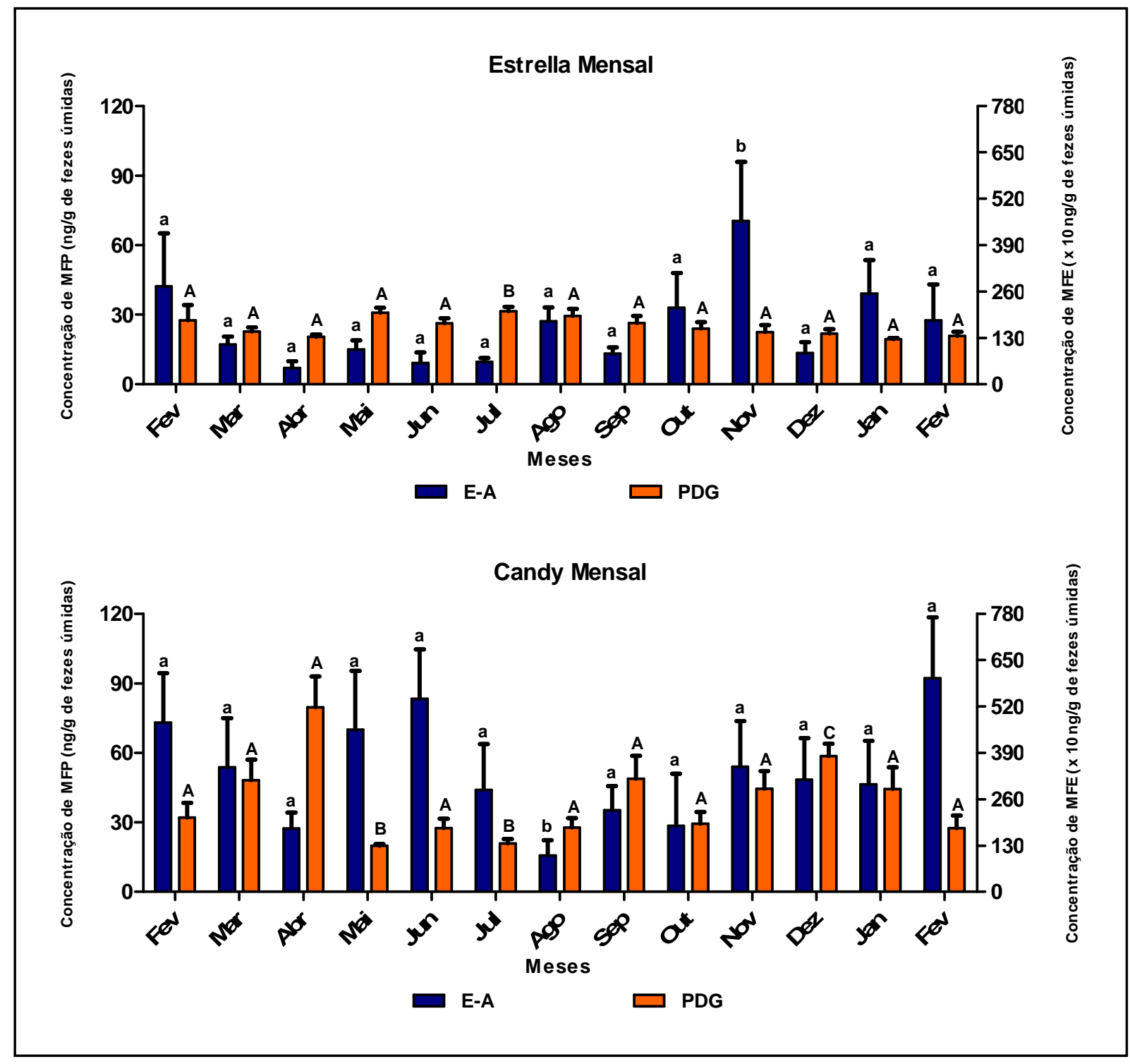

Legenda: Os dados são apresentados com Média \pm Erro padrão das médias, para cada metabólito. As letras diferentes representam diferencia estatística significativa entre meses 
Quanto às fêmeas do PATPAL, para a Susy, não houve diferença estatística para os valores de MFE, mas já entre as médias das concentrações mensais de MFP se observou que houve diferença apenas entre os meses de Abril de 2010 e Janeiro de $2011(p<0,05)$, onde a média desse mês foi menor, em relação aos outros meses. No caso da Luna foi observada diferença nos MFE para os meses de Abril, Outubro e Novembro contra os meses de Agosto e Setembro $(p<0,05)$, onde as médias dos MFE foram maiores quando comparadas com os outros meses. Este período coincide com a aparente ocorrência de ovulação. Com relação às médias dos MFP não foi encontrada diferença, inclusive entre as médias dos meses onde podem ter ocorrido ovulações, baseados nos resultados da análise longitudinal. Para a Estrella, em relação aos MFE foram observadas diferenças entre os meses de Abril e Junho e o mês de Novembro, sendo este o que apresenta os valores mais altos. Para os MFP foi encontrada uma diferencia entre os meses de Abril de 2010 e Janeiro de 2011 frente ao mês de Julho $2010(p<0,05)$, sendo que Abril e Janeiro foram muito menores quanto o Julho. Analisando este resultado em conjunto com os da análise longitudinal, houve possivelmente atividade ovariana, porém sem ocorrência de ovulação. No caso da Candy, para os MFE foram encontradas diferenças estatísticas entre o mês de Junho e Agosto de $2010 \quad(p<0,05)$, sendo deste período as concentrações mais baixas em relação ao ano todo. Para os valores de MFP foram encontradas diferenças entre os meses de Abril frente a Maio e Julho, e entre Maio e Julho frente a Dezembro; sendo que em Abril e Dezembro ocorreram as concentrações de MFP mais altas em todo o ano. Estes dados respaldam a sugestão de ovulação que foi observada na análise longitudinal. 


\subsubsection{Análise sazonal}

No gráfico 8 se apresentam os resultados das concentrações de metabólitos hormonais consolidadas por estações do ano nas seis fêmeas estudadas. Os resultados serão discutidos individualmente. 
Gráfico 8 - Concentrações médias e erros-padrão consolidados por estações do ano dos metabólitos fecais de estradiol (E-A) e progesterona (PDG) nas seis fêmeas estudadas
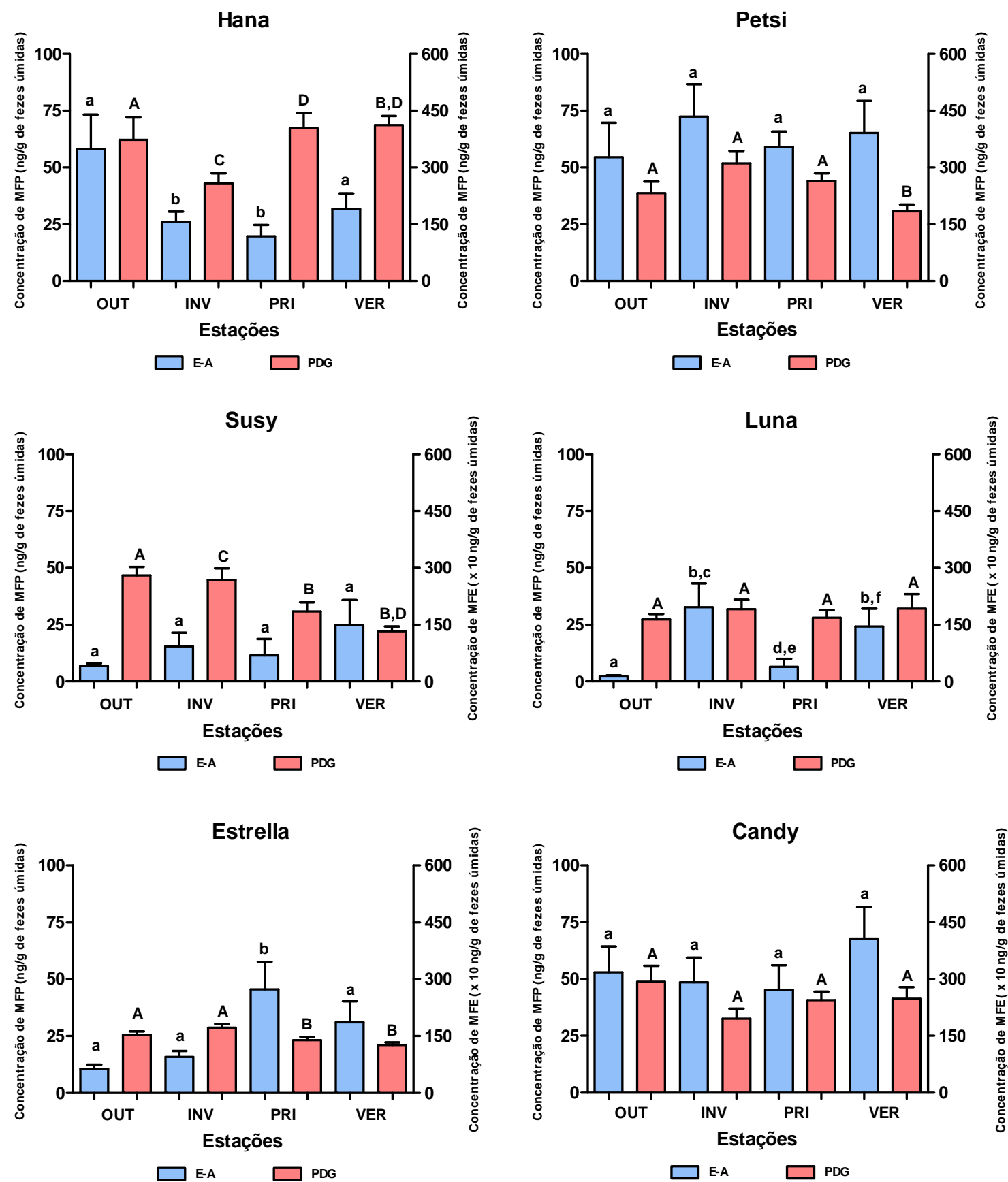

Legenda: Os dados são apresentados com Média \pm Erro padrão das médias, para cada metabólito. As letras diferentes representam diferencia estatística significativa entre estações 
Em relação às fêmeas do $\mathrm{PZH}$, para a Hana, segundo os resultados das comparações das médias das concentrações de MFE, pode se observar uma diferença estatística significativa $(p<0,05)$ entre as estações de Outono frente o Inverno e Primavera, sendo que nestas estações as médias das concentrações foram as mais baixas. Já com o MFP houve diferencia estatística entre as estações de Outono e Verão, onde Outono apresentou uma média menor quanto o Verão; e entre Inverno com Primavera e Verão, onde o Inverno teve a média menor. Estes resultados sugerem uma maior atividade ovariana na estação do Outono. Na Petsi, segundo o teste estatístico não houve diferencia significativa para os MFE ao longo das quatro estações do ano, mas para os MFP houve uma diferença significativa $(p<0,05)$ nas estações Inverno e Primavera, frente ao Verão, o qual apresentou a média das concentrações menor que as outras duas estações, e pode sugerir uma fase lútea durante o Inverno e Primavera.

No caso das fêmeas do PATPAL, para a Susy não houve diferencia significativa para os MFE ao longo das quatro estações do ano, porém, para os MFP houve uma diferença significativa $(p<0,05)$ na estação de Outono frente à Primavera e Verão, sendo que para estas duas, as médias das concentrações foram menores; da mesma forma, houve diferença entre Inverno e Verão, onde o Inverno apresentou uma média maior do que o Verão. Estes resultados podem indicar uma fase lútea no Outono e Inverno. No caso da Luna, segundo os resultados das comparações das médias das concentrações de MFE, pode se observar uma diferença estatística significativa $(p<0,05)$ entre as estações de Outono frente ao Inverno e Verão, onde Outono apresentou o valor da média das concentrações do MFE menor do que as outras duas estações. Da mesma maneira, a Primavera apresentou uma média menor com relação ao Inverno e Verão, sendo que estes dados sugerem uma maior 
atividade ovariana nestas duas estações. Para os MFP não houve diferencia significativa ao longo das quatro estações do ano. Em relação aos resultados da Estrella, pode se observar uma diferença estatística significativa $(p<0,05)$ nas concentrações de MFE entre as estações de Outono e Primavera, sendo que nesta o valor das médias foi o maior e sugere uma clara atividade ovariana nesta estação. Já com o MFP houve diferencia estatística entre as estações de Inverno frente à Primavera e Verão, onde o Inverno apresentou uma média maior do que as outras duas estações, sugerindo a aparição de uma fase lútea no Inverno. No caso da Candy não se observou diferença estatística nem nos valores das médias dos MFE e nem dos MFP. No entanto, pode se notar uma atividade ovariana e lútea, caracterizada pelos valores elevados das médias das concentrações, dado que apoia o observado na análise longitudinal.

Apesar das fêmeas aparentemente apresentarem a tendência de seguir o padrão reprodutivo sazonal descrito para a espécie, somente a Hana demonstrou claramente esta característica, sendo que a atividade folicular e lútea foi vista em diferentes meses do ano para os demais animais. Este fato também é relatado no Urso Solar (Helarctos malayanus), que quando mantido em cativeiro deixa de ser uma espécie como reprodução sazonal (GARSHELIS, 2004; FREDERICK et al., 2012). Assim, baseando-se nestes resultados, pode se sugerir que o Urso-de-óculos é uma espécie de sazonalidade facultativa conforme o sugerido pela literatura (PEYTON, 1999; SPADY; LINDBURG; DURRANT, 2007; GARCÍA-RANGEL, 2012). 


\subsection{Considerações finais}

O estudo foi realizado com animais em cativeiro fora do Brasil porquanto ao inicio da amostragem nenhum zoológico brasileiro tinha fêmeas adultas de Urso-deóculos na sua posse. Além disso, se trabalhou com um número amostral reduzido pela reticência à colaboração de algumas instituições zoológicas do Peru que tinham fêmeas nas suas coleções. Apesar disto os resultados obtidos permitiram responder as perguntas levantadas.

Em relação à validação fisiológica/indução da ovulação, o fato da inexistência de uma dose específica de GnRH para T. ornatus, dificultou o estudo e interferiu com a consistência dos resultados, ainda porque apenas foram duas fêmeas testadas. Em futuros trabalhos recomenda-se testar diferentes doses de $\mathrm{GnRH}$ para obter respostas mais consistentes no caso da progesterona.

Nosso trabalho é o primeiro estudo longitudinal de monitoramento hormonal na fêmea do Urso-de-óculos feito no hemisfério sul e na área de ocorrência da espécie, com um número de animais e amostragem maior do que nos estudos realizados na Europa (DEHNHARD et al., 2006); assim constitui-se numa referência para futuros estudos reprodutivos em $T$. ornatus. 



\section{CONCLUSÕES}

De acordo às condições do estudo, foi possível validar fisiologicamente o ensaio para dosagem de metabolitos fecais de estradiol, em fezes de Ursode-óculos, submetido a um desafio com GnRH.

Foi possível descrever e monitorar endócrinamente de forma não-invasiva os ciclos ovarianos do $T$. ornatus com o uso de extração e dosagem de metabólitos fecais de esteroides sexuais.

Os resultados demonstram que o Urso-de-óculos no cativeiro é uma espécie que conta com uma reprodução não sazonal, com fases folicular e lútea durando em média 08 e 22 dias, respectivamente.

T. ornatus apresenta em média, de três a quatro fases de atividade ovarianas por ano, quando em cativeiro. 



\section{REFERÊNCIAS}

ABÁIGAR, T.; DOMENÉ, M. A.; PALOMARES, F. Effects of fecal age and seasonality on steroid hormone concentration as a reproductive parameter in field studies. European Journal of Wildlife Research, v. 56, n. 5, p. 781-787, 2010.

AMSTISLAVSKY, S.; LINDEBERG, H.; LUVONI, G. Reproductive technologies relevant to the genome resource bank in Carnivora. Reproduction in Domestic Animals, v. 47, n. 1, p. 164-175, 2012.

BAMBERG, E.; MOSTL, E.; PATZL, M.; KING, G. Pregnancy diagnosis by enzyme immunoassay of estrogens in feces from nondomestic species. Journal of Zoo and Wildlife Medicine, v. 22, n. 1, p. 73-77, 1991.

BLOXAM, Q. Breeding the Spectacled bear at the Jersey Zoo. International Zoo Yearbook, v. 17, n. 1, p. 158-161, 1977.

BOONE, W. R.; CATLIN, J. C.; CASEY, K. J.; BOONE, E. T.; DYE, P. S.; SCHUETT, R. J.; ROSENBERG, J. O.; TSUBOTA, T.; BAHR, J. M. Bears as induced ovulators-A preliminary study. Ursus, v. 10, n. 1, p. 503-505, 1998.

BOONE, W. R.; KECK, B. B.; CATLIN, J. C.; CASEY, K. J.; BOONE, E. T.; DYE, P. S.; SCHUETT, R. J.; ROSENBERG, J. O.; TSUBOTA, T.; BAHR, J. M. Evidence that bears are induced ovulators. Theriogenology, v. 61, n. 6, p. 1163-1169, 2004.

BORQUE, C.; PEREZ-GARNELO, S. S.; LOPEZ, M.; TALAVERA, M. S.; DELCLAUX, M.; FUENTE, J. Validating a commercially available enzyme immunoassay for the determination of $17 \beta$-estradiol and progestogens in the feces 0 cheetahs (Acinonyx jubatus): A case report. Journal of Zoo and Wildlife Medicine, v. 36, n. 1 , p. $54-61,2005$.

BRACHO, A. E. Guía para el mantenimiento de Osos Andinos (Tremarctos ornatus) en cautiverio. Una propuesta para los Zoológicos de Latinoamérica. Mérida, Venezuela: Red Tremarctos, ZCOG Fundación Zoológica, Fundación AndígenA, 2002. $24 \mathrm{p}$. 
BROWN, A. D.; RUMIZ, D. I. Habitat and distribution of the Spectacled bear (Tremarctos ornatus) in the southern limit of its range. In INTERNATIONAL SYMPOSIUM OF SPECTACLED BEAR, 1., 1988, Chicago. Proceedings...

Chicago: Lincoln Park Zoological Gardens, Chicago Park District Press, 1989. v. 1, p. 93-103.

BROWN, J. L.; TERIO, K. A.; GRAHAM, L. H. Fecal androgen metabolite analysis for non invasive monitoring of testicular steroidogenic activity in felids. Zoo Biology, $v$. 15, n. 4, p. 424-434, 1996.

BROWN, J. L.; WASSER, S. K.; WILDT, D. E.; GRAHAM, L. H. Comparative aspects of steroid hormone metabolism and ovarian activity in felids, measured noninvasively in feces. Biology of Reproduction, v. 51, n. 4, p. 776-786. 1994.

BROWN, J. L.; WILDT, D. E. Assessing reproductive status in wild felids by non invasive faecal steroid monitoring. International Zoo Yearbook, v. 35, n. 1, p. 173$191,1997$.

CASTELLANOS, A. Preliminary results of the three-year telemetry study of Andean bear in the Intag Region, Ecuador. In: INTERNATIONAL CONFERENCE ON BEAR RESEARCH AND MANAGEMENT, 16., 2005, Riva del Garda. Proceedings... Riva del Garda-Trentino: International Association for Bear Research \& Management (IBA), 2005. v. 1, p. 43.

CASTELLANOS, A.; ALTAMIRANO, M.; TAPIA, G. Ecology and behaviour of reintroduced Andean bears in the Biological Reserve Maquipucuna, Ecuador: implications in conservation. Ukuku, Boletín Informativo sobre la Conservación del Oso Andino, v. 3, n. 1, p. 23-26, 2001.

CHRISTIANSEN, P. Feeding ecology and morphology of the upper canines in bears (carnivora: Ursidae). Journal of Morphology, v. 269, n. 7, p. 896-908, 2008.

CONVENÇÃO sobre o comercio internacional de espécies ameaçadas de fauna e flora silvestres (CITES). Apêndices I, II e III. Convenção sobre o Comercio Internacional de Espécies Ameaçadas de Fauna e Flora Silvestres. 2009, Disponível em: <http://www.cites.org/esp/append/appendices.shtml>. Acesso em: 04 jun. 2009. 
COCKREM, J. F.; ROUNCE, J. R. Faecal measurements of oestradiol and testosterone allow the non-invasive estimation of plasma steroid concentration in the domestic fowl. British Poultry Science, v. 35, n. 3, p. 433-443, 1994.

COMIZZOLI, P.; MERMILLOD, P.; MAUGET, R. Reproductive biotechnologies for endangered mammalian species. Reproduction Nutrition Development, v. 40, n. 5, p. 493-504, 2000.

CZEKALA, N. M.; DURRANT, B. S.; CALLISON, L.; WILLIAMS, M.; MILLARD, S. Fecal steroid hormone analysis as an indicator of reproductive function in the cheetah. Zoo Biology, v. 13, n. 2, p. 119-128. 1994.

DATHE, H. Bemerkungen zur Aufzucht von Brillenbaren (Tremarctos ornatus Cuvier) im Tierpark Berlin. Der Zoologishe Garten, Leipzig, v. 34, n. 1/2, p. 105-133, 1967.

DEHNHARD, M.; CLAUSS, M.; LECHNER-DOLL, M.; MEYER, H. H. D.; PALME, R. Noninvasive monitoring of adrenocortical activity in roe deer (Capreolus capreolus) by measurement of fecal cortisol metabolites. General and Comparative Endocrinology, v. 123, n. 1, p. 111-120, 2001.

DEHNHARD, M.; HILDEBRANDT, T. B.; KNAUF, T.; JEWGENOW, K.; KOLTER, L.; GÖRITZ, F. Comparative endocrine investigations in three bear species based on urinary steroid metabolites and volatiles. Theriogenology, v. 66, n. 6-7, p. 17551761, 2006.

DEL MORAL, J. F.; BRACHO A. E. Indicios indirectos de la presencia del oso andino en el noroeste de Argentina. Revista del Museo Argentino de Ciencias Naturales, v. 11, n. 1, p. 69-76, 2009.

EMMONS, L.; FEER, F. Mamíferos de los bosques húmedos de América tropical. Santa Cruz de la Sierra: Editorial FAN, 1999. 298 p.

ENCISO, M. A.; GÁLVEZ-ROEDER, D.; LA TORRE, J. Pursuing the Spectacled bear footprint at the Huiquilla's forest, northern Peruvian Yungas. International Bear News, v. 21, n. 1, p. 45-47, 2012. 
FIGUEROA, J. Cacería del Oso Andino en el Perú: Comercio y etnozoología. Lima: Cooperación Técnica Alemana-GTZ/FANPE e Proyecto Oso Andino-Perú, 2003. 66 p.

FIGUEROA, J.; STUCCHI, M. Situación actual del Oso Andino en el santuario histórico de machu picchu y zonas adyacentes, cusco, Perú. Lima: Cooperación Técnica Alemana-GTZ/FANPE e Proyecto Oso Andino-Perú, 2002. 113 p.

FIGUEROA, J.; STUCCHI, M. Las cactáceas en la dieta del oso andino Tremarctos ornatus en el Perú. Quepo, Sociedad Peruana de Cactus y Suculentas, v. 22, n. 1, p. 21-28, 2008.

FIGUEROA, J.; STUCCHI, M. EI Oso Andino: alcances sobre su historia natural. Lima: Asociación para la Investigación y Conservación de la Biodiversidad (AICB), 2009. $105 \mathrm{p}$.

FREDERICK, C.; KYES, R.; HUNT, K.; COLLINS, D.; DURRANT, B.; WASSER, S. $\mathrm{K}$. Methods of estrus detection and correlates of the reproductive cycle in the sun bear (Helarctos malayanus). Theriogenology, v. 74, n. 7, p. 1121-1135, 2010.

FREDERICK, C.; HUNT, K. E.; KYES, R.; COLLINS, D.; WASSER, S. K. Reproductive timing and aseasonality in the sun bear (Helarctos malayanus). Journal of Mammalogy, v. 93, n. 2, p. 522-531, 2012.

GARCÍA-RANGEL, S. Andean bear Tremarctos ornatus natural history and conservation. Mammal Review, v. 42, n. 2, p. 85-119, 2012.

GARSHELIS, D. L. Variation in ursid life histories: is there an outlier? In: LINDBURG, D.; BARAGONA, K. (Ed). Giant pandas, biology and conservation. Los Angeles: University of California Press, 2004. p. 55-73.

GARSHELIS, D. L. Family ursidae. In: WILSON, D. E.; MITTERMEIER, R. A. (Ed).Handbook of the mammals of the world. Barcelona: Lynx Edicions, 2009. v. 1, p. 448-498. 
GRAHAM, L. H.; BYERS, A. P.; ARMSTRONG, D. L.; LOSKUTOFF, N. M.; SWANSON, W. F.; WILDT, D. E.; BROWN, J. L. Natural and gonadotropin-induced ovarian activity in tigers (Panthera tigris) assessed by fecal steroid analyses. General and Comparative Endocrinology, v. 147, n. 3, p. 362-370, 2006.

GRAHAM, L. H.; SCHWARZENBERGER, F.; MÖSTL, E.; GALAMA, W.; SAVAGE, A. A versatile enzyme immunoassay for the determination of progestagens in feces and serum. Zoo Biology, v. 20, n. 3, p. 227-236, 2001.

GOLDSTEIN, I.; PAISLEY, S.; WALLACE, R. B.; JORGENSON, J. P.; CUESTA, F.; CASTELLANOS, A. Andean bear-livestock conflicts: a review. Ursus, v. 17, n. 1, p. 8-15, 2006.

GOLDSTEIN, I.; GUERRERO, V.; MORENO, R. Are there Andean bears in Panama?. Ursus, v. 19, n. 2, p. 185-189, 2008a.

GOLDSTEIN, I.; VELEZ-LIENDO, X.; PAISLEY, S.; GARSHELIS, D. L. Tremarctos ornatus. Huntingdon Road: IUCN 2008, IUCN Red List of Threatened Species. 2008b, Disponível em: <http://www.iucnredlist.org/details/22066>. Acesso em: 04 jun. 2009.

GÓMEZ-CASTAÑEDA, L. Una osa llegó a la familia de los osos frontinos venezolanos. Natura (Venezuela), v. 105, n. 1, p. 66, 1996.

HEISTERMANN, M.; TARI, S.; HODGES, J. K. Measurement of faecal steroids for monitoring ovarian function in New World primates, Callitrichidae. Journal of Reproduction and Fertility, v. 99, n. 1, p. 243-251, 1993.

HEISTERMANN, M.; PALME, R.; GANSWINDT, A. Comparison of different enzymeimmunoassays for assessment of adrenocortical activity in Primates based on fecal analysis. American Journal of Primatology, v. 68, n. 3, p. 257-273, 2006.

HILDERBRAND, G. V.; JENKINS, S. G.; SCHWARTZ, C. C.; HANLEY, T. A.; ROBBINS, C. T. Effect of seasonal differences in dietary meat intake on changes in body mass and composition in wild and captive brown bears. Canadian Journal of Zoology, v. 77, n. 10, p. 1623-1630, 1999. 
HOLT, W. V.; PICKARD, A. R. Role of reproductive technologies and genetic resource banks in animal conservation. Reviews of Reproduction, v. 4, n. 3, p. 143150, 1999.

ISHIKAWA, A.; KIKUCHI, S.; KATAGIRI, S.; SAKAMOTO, H.; TAKAHASHI, Y. Efficiency of fecal steroid hormone measurement for assessing reproductive function in the Hokkaido brown bear (Ursus arctos yesoensis). Japanese Journal of Veterinary Research, v. 50, n. 1, p. 17-27, 2002.

ISHIKAWA, A.; SAKAMOTO, H.; KATAGIRI, S.; TAKAHASHI, Y. Changes in sexual behavior and fecal steroid hormone concentrations during the breeding season in female Hokkaido brown bears (Ursus arctos yesoensis) under captive condition. Journal of Veterinary Medical Science, v. 65, n. 1, p. 99-102, 2003.

INTERNATIONAL UNION OF CONSERVATION OF NATURE AND NATURAL RESOURCES (IUCN). IUCN Red List of Threatened Species. Version 2012.2. 2012a. Disponível em: <http://www.iucnredlist.org >. Acesso em: 17 dez. 2012.

INTERNATIONAL UNION OF CONSERVATION OF NATURE AND NATURAL RESOURCES (IUCN). IUCN Red List Categories and Criteria. Version 3.1. 2. ed. Gland, Switzerland and Cambrigde: IUCN, 2012b. p. 32.

JIMENEZ, C.; QUINTANA, H.; PACHECO, V.; MELTON, D.; TORREALVA, J.; TELLO, G. Camera trap survey of medium and large mammals in a montane rainforest of northern of Peru. Revista Peruana de Biologia, v. 17, n. 2, p. 191-196, 2010.

JOHANNSSON, A. Principies and practice of immunoassay. New York: Ed. McMillan, 1991. 300 p.

KERSEY, D. C.; WILDT, D. E.; BROWN, J. L.; SNYDER, R. J.; HUANG, Y.; MONFORT, S. L. Unique biphasic progestagen profile in parturient and nonparturient giant pandas (Airulopoda melanoleuca) as determined by faecal hormone monitoring. Reproduction, v. 140, n. 1, p. 183-193, 2010. 
KINOSHITA, K.; INADA, S.; SEKI, K.; SASAKI, A.; HAMA, N.; KUSUNOKI, H. Longterm monitoring of fecal steroid hormones in female Snow Leopards (Panthera uncia) during pregnancy or pseudopregnancy. PLoS ONE, v. 6, n. 5, p. e19314, 2011.

KIRKPATRICK, J. F.; GUDERMUTH, D. F.; FLAGAN, R. L.; MCCARTHY, J. C.; LASLEY, B. L. Remote monitoring of ovulation and pregnancy of Yellowstone bison. Journal of Wildlife Management, v. 57, n. 2, p. 407-412, 1993.

KOHLER, I. V.; PRESTON, S. H.; LACKEY, L. B. Comparative mortality levels among selected species of captive animals. Demographic Research, v. 15, n. 14, 413-434, 2006.

KURTÉN, B. Pleistocene bears of North America: Genus Tremarctos, spectacled bears. Acta Zoologica Fennica, v. 115, n. 1, p. 1-96, 1966.

LASLEY, B. L.; KIRKPATRICK, J. F. Monitoring ovarian function in captive and freeranging wildlife by means of urinary and fecal steroids. Journal of Zoo and Wildlife Medicine, v. 22, n. 1, p. 23-31, 1991.

MARGULES, C. R.; PRESSEY, R. L. Systematic conservation planning. Nature, v. 405, n. 6783, p. 243-253, 2000.

MILLSPAUGH, J. J.; WASHBURN, B. E. Use of fecal glucocorticoid metabolite measures in conservation biology research: considerations for application and interpretation. General and Comparative Endocrinology, v. 138, n.3, p. 189-199, 2004.

PERÚ. Ministerio del Ambiente (MINAM). Informe final del estudio de especies CITES de carnívoros peruanos. Lima: Ministerio del Ambiente, Dirección General de Diversidad Biológica (DGDB), 2011, 162 p.

MONDOLFI, E. El oso frontino. Defensa de la Naturaleza (Venezuela), v. 1, n. 1, p. 31-35, 1971. 
MONFORT, S. L. Non-invasive endocrine measures of reproduction and stress in wild populations. In: HOLT, W. V.; PICKARD, A. R.; RODGER, J. C.; WILDT, D. E. (Ed.). Reproductive science and integrated conservation. Cambridge: Cambridge University Press, 2003. p. 147-165.

MOREIRA, N.; MONTEIRO-FILHO, E. L. A.; MORAES, W.; SWANSON, W. F.; GRAHAM, L. H.; PASQUALI, O. L.; GOMES, M. L. F.; MORAIS, R. N.; WILDT, D. E.; BROWN, J. L. Reproductive steroid hormones and ovarian activity in felids of the Leopardus genus. Zoo Biology, v. 20, n. 2, p. 103-116, 2001.

MÖSTL, E.; PALME, R. Measuring faecal steroid metabolites with enzyme immunoassays (EIA) on microtitre plates using biotinylated steroids as labels. Vienna: Dept. Biomed. Sciences/Biochemistry, University of Veterinary Medicine. 2010. Disponível em: <http://www.vu-wien.ac.at/biochemie/>. Acesso em: 23 jan. 2012.

MÖSTL, E.; RETTENBACHER, S.; PALME, R. Measurement of corticosterone metabolites in birds' droppings: An analytical approach. Annals of New York Academy of Sciences, v. 1046, n. 1, p. 17-34, 2005.

MUELLER, P. Observations on behavior and reproductive biology of Spectacled bears (Tremarctos ornatus) at the Leipzig Zoological Garden. INTERNATIONAL SYMPOSIUM OF SPECTACLED BEAR, 1., 1988, Chicago. Proceedings...

Chicago: Lincoln Park Zoological Gardens, Chicago Park District Press, 1989. v. 1, p. 209-220.

MUNRO, C. J.; STABENFELDT, G. H.; CRAGUN, J. R.; ADDIEGO, L. A.; OVERSTREET, J. W.; LASLEY, B. L. Relationship of serum estradiol and progesterone concentrations to the excretion profiles of their major urinary metabolites as measured by enzyme immunoassay and radioimmunoassay. Clinical Chemistry, v. 37, n. 6, p. 838-844, 1991.

MYERS, N.; MItTERMEIER, R. A.; MITTERMEIER, C. G.; DA FONSECA, G. A. B.; KENT, J. Biodiversity hotspots for conservation priorities. Nature, v. 403, n. 6772, p. 853-858, 2000.

ONUMA, M.; SUZUKI, M.; UCHIDA, E.; NIIYAMA, N.; OHTAISHI, N. Annual changes in fecal estradiol-17beta concentrations of the sun bear (Helarctos malayanus) in Sarawak, Malaysia. Journal of Veterinary Medical Sciences, v. 64, n. 4, p. 309313, 2002. 
PAISLEY, S. L. Andean bear and people in Apolobamba, Bolivia: culture, conflict and conservation. 2001. 306 f. Tese (Doutorado) - University of Kent, Kent, 2001.

PALME, R. Measuring fecal steroids: guidelines for practical application. Annals of New York Academy of Sciences, v. 1046, n. 1, p. 75-80, 2005.

PALME, R.; FISCHER, P.; SCHILDORFER, H.; ISMAIL, M. N. Excretion of infused ${ }^{14} \mathrm{C}$-steriod hormones via faeces and urine in domestic livestock. Animal

Reproduction Science, v. 43, n. 1, p. 43-63, 1996.

PALME, R.; MÖSTL, E. Measurement of cortisol metabolites in faeces of sheep as a parameter of cortisol concentration in blood. International Journal of Mammalian Biology, v. 62, Suppl. II, p. 192-197, 1997.

PALME, R.; RETTENBACHER, S.; TOUMA, C.; EL-BAHR, S. M.; MÖSTL, E. Stress hormones in mammals and birds. Comparative aspects regarding metabolism, excretion, and noninvasive measurement in fecal samples. Annals of New York Academy of Sciences, v. 1046, n. 1, p. 162-171, 2005.

PEREIRA, R. J. G.; POLEGATO, B. F.; SOUZA, S.; NEGRÃO, J. A.; DUARTE, J. M. $B$. Monitoring ovarian cycles and pregnancy in Brown brocket deer (Mazama gouazoubira) by measurement of fecal progesterone metabolites. Theriogenology, v. 65 , n. 2, p. 387-399, 2006.

PETTITT, B. A.; WHEATON, C. J.; WATERMAN, J. M. Effects of storage treatment on fecal steroid hormone concentrations of a rodent, the Cape ground squirrel (Xerus inauris). General and Comparative Endocrinology, v. 150, n. 1, p. 1-11, 2007.

PEYTON, B. Ecology, distribution and food habits of Spectacled bear, Tremarctos ornatus, in Peru. Journal of Mammalogy, v. 61, n. 4, p. 639-652, 1980.

PEYTON, B. Habitat components of the Spectacled bear. International Conference on Bear Research and Management, v. 7, n. 1, p. 127-133, 1987a.

PEYTON, B. Criteria for assessing habitat quality of the Spectacled bear in Machu Picchu, Peru. International Conference on Bear Research and Management, v. 7, n. 1, p. 135-143, 1987b. 
PEYTON, B. Spectacled bear conservation action plan. In: SERVHEEN, C.; HERRERO, S.; PEYTON, B.. (Ed.). Bears. Status survey and conservation action plan. Switzerland and Cambridge: IUCN/SCC Bear Specialist Group. Switzerland and Cambridge, 1999. p. 157-198.

PEYTON, B.; YERENA, E.; RUMIZ, D.; JORGENSON, J.; OREJUELA, J. Status of wild Andean bears and policies for their management. Ursus, v. 10, n. 1, p. 87-100, 1998.

POWELL, R. A.; ZIMMERMAN, J. W.; SEAMAN, D. E. Ecology and behaviour of North American black bears: home ranges, habitat and social organization. Wildlife Ecology and Behavior Monograph Series, v. 4, n. 1, p. 1-197, 1997.

RANDALL, R. Qoyllur Rit'i, and Inca fiesta of the pliedes: reflections on time and space in the Andean world. Bulletin de I'Institut Français d'Etudes Andines, v. 11, n. 1, p. 37-81, 1982.

RÍOS-MEJÍA, P. Reporte del primer nacimiento viable y crianza de Oso de Anteojos (Tremarctos ornatus) en un centro de crianza ex situ del Perú. Boletín Virtual Fauna-Vet (Perú), v. 1, n. 4, p. 4-7, 2008.

RODRÍGUEZ-CLARK, K. M.; SÁNCHEZ-MERCADO, A. Population management of threatened taxa in captivity within their natural ranges: lessons from Andean bears (Tremarctos ornatus) in Venezuela. Biological Conservation, v. 129, n. 1, p. 134148, 2006.

ROJAS-VERAPINTO, R.; GÁLVEZ-ROEDER, D.; ENCISO, M. A. Cultural zoogeography of the Andean bear around Cordillera Azul National Park, Department of San Martín, northeastern Peru. International Bear News, v. 19, n. 2, p. 24-25, 2010.

ROSENTHAL, M. Official historical register for all Spectacled bears. In:

WEINHARDT, D. (Ed.). International studbook for the spectacled bear. 1986.

Chicago: Lincoln Park Zoological Gardens, Chicago Park District Press, 1987a. p. 11-28. 
ROSENTHAL, M. Biological management of Spectacled bears (Tremarctos ornatus) in captivity. In: WEINHARDT, D. (Ed.). International studbook for the spectacled bear, 1986. Chicago: Lincoln Park Zoological Gardens, Chicago Park District Press, 1987b. p. 93-103.

ROSENTHAL, M. Spectacled bears - an overview of management practices. In: INTERNATIONAL SYMPOSIUM OF SPECTACLED BEAR, 1., 1988, Chicago. Proceedings... Chicago: Lincoln Park Zoological Gardens, Chicago Park District Press, 1989. v. 1, p. 287-300.

SACCO, T.; VAN VALKENBURGH, B. Ecomorphological indicators of feeding behaviour in the bears (Carnivora: Ursidae). Journal of Zoology, v. 263, n. 1, p. 4154, 2004.

SCHIPPER, J.; CHANSON, J. S.; CHIOZZA, F.; COX, N. A.; HOFFMANN, M.; KATARIYA, V.; LAMOREUX, J.; RODRIGUES, A.S.L.; STUART S. N.; TEMPLE, H. J.; BAILLIE, J.; BOITANI, L.; LACHER JR., T. E.; MITTERMEIER, R. A.; SMITH, A. T.; ABSOLON, D.; AGUIAR, J. M.; AMORI, G.; BAKKOUR, N.; BALDI, R.; BERRIDGE, R. J.; BIELBY, J.; BLACK, P. A.; BLANC, J. J.; BROOKS, T. M.; BURTON, J. A.; BUTYNSKI, T. M.; CATULLO, G.; CHAPMAN, R.; COKELISS, Z.; COLLEN, B.; CONROY, J.; COOKE, J. G.; DA FONSECA, G. A. B.; DEROCHER, A.; DUBLIN, H. T.; DUCKWORTH, J. W.; EMMONS, L.; EMSLIE, R.; FESTABIANCHET, M.; FOSTER, M.; FOSTER, S.; GARSHELIS, D. L.; GATES, C.; GIMENEZ-DIXON, M.; GONZALEZ, S.; GONZALEZ-MAYA, J. F.; GOOD, T. C.; HAMMERSON, G.; HAMMOND, P. S.; HAPPOLD, D.; HAPPOLD, M.; HARE, H.; HARRIS, R.B.; HAWKINS, C. E.; HAYWOOD, M.; HEANEY, L. R.; HEDGES, S.; HELGEN, K. M.; HILTON-TAYLOR, C.; HUSSAIN, S. A.; ISSHII, N.; JEFFERSON, T. A.; JENKINS, R. K. B.; JOHNSTON, C. H.; KEITH, M.; KINGDON, J.; KNOX, D. H.; KOVACS, K. M.; LANGHAMMER, P.; LEUS, K.; LEWINSON, R.; LICHTENSTEIN, G.; LOWRY, L. F.; MACAVOY, Z.; MACE, G. M.; MALLON, D. P.; MASI, M.; MCKNIGHT, M. W.; MEDELLÍN, R. A.; MEDICI, P.; MILLS, G.; MOEHLMAN, P. D.; MOLUR, S.; MORA, A.; NOWELL, K.; OATES, J. F.; OLECH, W.; OLIVER, W. R. L.; OPREA, M.; PATTERSON, B. D.; PERRIN, W. F.; POLIDORO, B. A.; POLLOCK, C.; POWEL, A.; PROTAS, Y.; RACEY, P.; RAGLE, J.; RAMANI, P.; RATHBURN, G.; REEVES, R. R.; REILLY, S. B.; REYNOLDS III, J. E.; RONDININI, C.; ROSELLAMBAL, R. G.; RULLI, M.; RYLANDS, A. B.; SAVINI, S.; SCHANK, C. J.; SECHREST, W.; SELF-SULLIVAN, C.; SHOEMAKER, A.; SILLERO-ZUBIRI, C.; SILVA, N. de; SMITH, D. E.; SRINIVASULU, C.; STEPHENSON, P. J.; VAN STRIEN, N.; TALUKDAR, B. K.; TAYLOR, B. L.; TIMMINS, R.; TIRIRA, D. G.; TOGNELLI, M. F.; TSYTSULINA, K.; VEIGA, L. M.; VIÉ, J.; WILLIAMSON, E. A.; WYATT, S. A.; XIE, Y.; YOUNG, B. E. The status of the world's land and marine mammals: diversity, threat, and knowledge. Science, v. 322, n. 5899, p. 225-230, 2008. 
SCHWARZENBERGER, F. The many uses of non-invasive faecal steroid monitoring in zoo and wildlife species. International Zoo Yearbook, v. 41, n. 1, p. 52-74, 2007.

SCHWARZENBERGER, F.; FREDIKSSON, G.; SCHALLER, K.; KOLTER, L. Fecal steroid analysis for monitoring reproduction in the sun bear (Helarctos malayanus). Theriogenology, v. 62, n. 9, p. 1677-1692, 2004.

SCHWARZENBERGER, F.; MOSTL, E.; PALME, R.; BAMBERG, E. Faecal steroid analysis for non-invasive monitoring o reproductive status in farm, wild and zoo animals. Animal Reproduction Science, v. 42, n. 1-4, p. 515-526, 1996.

SHIDELER, S. E.; ORTUÑO, A. M.; MORÁN, F. M.; MOORMAN, E. A.; LASLEY, B. L. Simple extraction and enzyme immunoassays for estrogen and progesterone metabolites in the feces of Macaca fascicularis during non-conceptive and conceptive ovarian cycles. Biology of Reproduction, v. 48, n. 6, p. 1290-1298, 1993.

SONGSASEN, N.; RODDEN, M.; BROWN, J. L.; WILDT, D. E. Patterns of fecal gonadal hormone metabolites in the maned wolf (Chrysocyon brachyurus).

Theriogenology, v. 66, n. 6-7, p. 1743-1750, 2006.

SPADY, T. J.; LINDBURG, D. G.; DURRANT, B. S. Evolution of reproductive seasonality in bears. Mammal Review, v. 37, n. 1, p. 21-53, 2007.

STAVISKY, R.; RUSSELL, E.; STALLINGS, J.; SMITH, E. O. Fecal steroids analysis of ovarian cycles in free-ranging baboons. American Journal of Primatology, v. 36, n. 4, p. 285-297, 1995.

STOOPS, M. A.; MACKINNON, K. M.; ROTH, T. L. Longitudinal fecal hormone analysis for monitoring reproductive activity in the female polar bear (Ursus maritimus). Theriogenology, v. 78, n. 9, p. 1977-1986, 2012.

SUÁREZ, L. Seasonal distribution and food habits of the Spectacled bear (Tremarctos ornatus) in the highlands of Ecuador. Studies on Neotropical Fauna and Environment, v. 23, n. 3, p. 133-136, 1989.

THENIUS, E. Zur stammesgeschichtlichen Herkunft von Tremarctos (Ursidae, Mammalia). Zeitschrift für Säugetierkunde, v. 41, n. 3, p. 109-114, 1976. 
THOMPSON, S. D. Zoo research and conservation: Beyond sperm and eggs toward the science of animal management. Zoo Biology, v. 12, n. 2, p. 155-159, 1993.

THOREL, J. I.; LARSON, S. M. Radioimmunoassay and related techniques. Saint Loius: The C.V. Mosby Company, 1978, 289 p.

TOUMA, C.; PALME, R. Measuring fecal glucocorticoid metabolites in mammals and birds: the importance of validation. Annals of the New York Academy of Sciences, v. 1046, n. 1, p. 54-74, 2005.

TSUJI, A.; MAEDA, M.; ARAKAWA, H. Chemiluminiscent enzyme immunoassay. A review. Analytical Sciences, v. 5, n. 5, p. 497-506, 1989.

VARGAS, C. Determinación de la fauna utilizada en la medicina tradicional en el departamento de Lambayeque. 1997. 66 f. Tese (Biólogo) - Faculdade de Ciências Biológicas, Universidad Nacional Pedro Ruiz Gallo, Lambayeque, 1997.

VELA, M.; VÁSQUEZ, G.; GALINDO, J.; PÉREZ, J. El Oso andino Sudamericano, su importancia y conservación. CIENCIA, Revista de la Academia Mexicana de Ciencias, v. 62, n. 2, p. 44-51, 2011.

VIAU, P.; FELIPPE, E. C. G.; OLIVEIRA, C. A. Quantificação de esteroides fecais de fêmeas de onça-pintada (Panthera onca) mantidas em cativeiro: Validação da técnica. Brazilian Journal of Veterinary Research and Animal Science, v. 42, n. 4, p. 267-275, 2005.

VIAU, P. Perfil analítico de estrógenos e progestinas em diferentes matrizes biológicas na espécie ovina (Ovis aries). 2007. $96 \mathrm{f}$. Tese (Doutorado em Reprodução Animal) - Faculdade de Medicina Veterinária e Zootecnia, Universidade de São Paulo, São Paulo, 2007.

WASSER, S. K; RISLER, L.; STEINER, R. A. Excreted steroids in primate feces over the menstrual cycle and pregnancy. Biology of Reproduction, v. 39, n. 4, p. 862 872, 1988. 
WILDT, D. E. Genetic resource banks for conserving wildlife species: justification, examples and becoming organized on a global basis. Animal Reproduction

Science, v. 28, n. 1-4, p. 247-257, 1992.

WILDT, D.; PUKAZHENTHI, B.; BROWN, J.; MONFORT, S.; HOWARD, J. ROTH, T. Spermatology for understanding, managing and conserving rare species.

Reproduction, Fertility and Development, v. 7, n. 4, p. 811-824, 1995.

WILDT, D. E.; RALL, W. F.; CRISTER, J. K.; MONFORT, S. L.; SEAL, U. S. Genome resource banks. Living collections for biodiversity conservation. Bioscience, v. 47, n. 10, p. 689-698, 1997.

ZIEGLER, T. E.; SCHEFFLER, G.; WITTWER, D. J.; SCHULTZ-DARKEN, N.; SNOWDON, C. T.; ABBOTT, D. H. Metabolism of reproductive steroids during the ovarian cycle in two species of callitrichids, Saguinus oedipus and Callithrix jacchus, and estimation of the ovulatory period from fecal steroids. Biology of Reproduction, v. 54, n. 1, p. 91-99, 1996.

ZIEGLER, T. E.; WITTWER, D. J. Fecal steroid research in the field and laboratory: Improved methods for storage, transport, processing and analysis. American Journal of Primatology, v. 67, n. 1, p. 159-174, 2005. 



\section{ANEXO A - Dieta dos Ursos-de-óculos nos dois Zoológicos estudados}

\section{Parque Zoológico Huachipa}

Pela manhã: $\quad$ Aveia com leite, mandioca, ovo e milho cozidos, frutas da época, ração para cachorro, pão.

Pela tarde: $\quad$ Mandioca, ovo e milho cozidos, frutas da época, ração para cachorro, pão.

Esporádicos: $\quad$ Frango cozido, carne de boi cozida, mel.

\section{Patronato Parque de Las Leyendas "Felipe Benavides Barreda"}

Pela manhã: $\quad$ Aveia com leite, pão, legumes cozidas: mandioca, batata doce; legumes frescos: cenoura, alface. Peixe cru, frango cozido. Ração para cachorro. Cana de açúcar. Frutas da época: mamão, melancia, uva, tangerina, banana, maça.

Pela tarde: Milho cozido. 